\title{
Tectonometamorphic discontinuities within the Greater Himalayan Sequence in Western Nepal (Central Himalaya): Insights on the exhumation of crystalline rocks
}

\author{
C. Montomoli a,e,*, S. Iaccarino a ${ }^{\mathrm{a}}$, R. Carosi ${ }^{\mathrm{b}}$, A. Langone $^{\mathrm{c}}$, D. Visonà ${ }^{\mathrm{d}}$ \\ a Dipartimento di Scienze della Terra, Via S. Maria 53, Pisa, Italy \\ b Dipartimento di Scienze della Terra, Via Valperga Caluso 35, Torino, Italy \\ c Istituto di Geoscienze e Georisorse, via Ferrata 1, Pavia, Italy \\ ' Dipartimento di Geoscienze, via Gradenigo 6, Padova, Italy \\ e Istituto di Geoscienze e Georisorse, via Moruzzi, Pisa, Italy
}

\section{A R T I C L E I N F O}

\section{Article history:}

Received 8 February 2013

Received in revised form 25 May 2013

Accepted 4 June 2013

Available online 14 June 2013

\section{Keywords:}

Himalayas

Greater Himalayan Sequence

Exhumation

Shear zone

High Himalayan Discontinuity

Monazite geochronology

\begin{abstract}
A B S T R A C T
The core of the Greater Himalayan Sequence in the Mugu-Karnali area (Western Nepal) is affected by a thick shear zone with development of nearly $4 \mathrm{~km}$ of mylonites (Mangri shear zone). It is a contractional shear zone showing a top-to-the-SW and WSW sense of shear. The shear zone developed during the decompression, in the sillimanite stability field, of rocks that previously underwent relatively high-pressure metamorphism deformed under the kyanite stability field. P-T conditions indicate that the footwall experienced higher pressure $(1.0-0.9 \mathrm{GPa})$ than the hanging wall $(0.7 \mathrm{GPa})$ and similar temperatures $\left(675^{\circ}-700{ }^{\circ} \mathrm{C}\right)$. $\mathrm{U}-\mathrm{Pb}$ in-situ dating of monazites indicate a continuous activity of the shear zone between 25 and $18 \mathrm{Ma}$. Samples from the lower part of the Greater Himalayan Sequence underwent similar ductile shearing at 17-13 Ma. These ages and the associated P-T-t paths revealed that peak metamorphic conditions were reached $\sim 5-7 \mathrm{Ma}$ later in the footwall of the shear zone with respect to the hanging-wall pointing to a diachroneity in the metamorphism triggered by the shear zone itself.

Mangri Shear Zone, with the other recently documented tectonic and metamorphic discontinuities within the Greater Himalayan Sequence, point to the occurrence of a regional tectonic feature, the High Himalayan Discontinuity, running for more than $500 \mathrm{~km}$ along the strike of the Central Himalayas. It was responsible of the exhumation of the upper part of the Greater Himalayan Sequence starting from $28 \mathrm{Ma}$, well before the activation of the Main Central Thrust and the South Tibetan Detachment.

Our data point out that exhumation of the Greater Himalayan Sequence was partitioned in space and time and different slices were exhumed in different times, starting from the older in the upper part to the younger in the lower one.
\end{abstract}

(c) 2013 Elsevier B.V. All rights reserved.

\section{Introduction}

Plate tectonics well-accounts for the occurrence of high-pressure metamorphism in collisional settings. However, the mechanisms explaining the exhumation of deep seated metamorphic rocks are not well-explained by the paradigms of plate tectonics and are nowadays debated. One of the main problem to face is the occurrence of HP or UHP rocks exhumed in the same collisional cycle in which they formed in still contractional tectonics. This is the case in the Alps and in the Himalayas (Platt, 1993). Their occurrence ruled out

\footnotetext{
* Corresponding author at: Dipartimento di Scienze della Terra, via S. Maria 53, 56126 Pisa, Italy. Tel.: + 390502215844

E-mail addresses: montomoli@dst.unipi.it (C. Montomoli), iaccarino@dst.unipi.it (S. Iaccarino), rodolfo.carosi@unito.it (R. Carosi), langone@igg.cnr.it (A. Langone), dario.visona@unipd.it (D. Visonà).
}

two of the main mechanisms generally adopted for the exhumation of deep-seated rocks such as erosion and extensional tectonics. In the nineties the discovery of thrusts and normal faults active on the same vertical section, in a still active collisional belt, leads to the formulation of a new model of extrusion both by observation in the Himalayas (Hodges et al., 1992) and analogue modelling (Chemenda et al., 1995). This one was the first model able to explain rapid syn-convergence exhumation of deep seated rocks in the Himalayas.

The Himalayan belt, derived from the collision at 55 Ma between India and Asia, is the most classical example of continent-continent collisional belt and it is a natural laboratory where several exhumation mechanisms were first described, so that it is the best place to test some of the generally accepted exhumation models.

Several first-order tectonic discontinuities have been recognised in the Himalayas that from bottom to top are: Main Frontal Thrust, Main Boundary Thrust, Main Central Trust (MCT) and South Tibetan 
Detachment (STD) (Gansser, 1964; Le Fort, 1975; Hodges, 2000 with references). The belt is characterised by the impressive continuity of these main structural discontinuities and tectonic units for nearly $2500 \mathrm{~km}$. Among these the MCT and STD bound the Greater Himalayan Sequence (GHS), containing the most metamorphic rocks of the Himalayas.

The main tectonic models proposed for the exhumation of GHS are (Fig. 1):

1) channel flow (Beaumont et al., 2001), in which the GHS represents a partially molten lower/middle crust (hot-channel) that tunnels southwards during the Eocene-Oligocene, a process driven by the lateral pressure gradient created by the gravitational potential difference between the Tibetan plateau and its margins. In this model MCT and STDS are contemporaneous and remain parallel and sub-horizontal;

2) wedge extrusion in which the GHS extruded southwards as a northward-tapering wedge, by combining thrust along MCT at its base and extension along STDS at the top of the unit, as: a) a rigid wedge (Hodges et al., 1992), b) a ductilely deformed wedge undergoing simple shear (Grujic et al., 1996), or c) a wedge deformed by non-coaxial general flow (Vannay and Grasemann, 2001);

3) channel flow followed by extrusion (Godin et al., 2006) in which the hot-channel is finally exhumed to the surface by extrusion, with the geometry of model 1), and enhanced by focused erosion at the topographic front of the orogen;

4) wedge insertion (Webb et al., 2007) in which the GHS is regarded as a wedge but differently from model 1), it has a southward-tapering geometry and the STDS is regarded as a back-thrust;

5) critical taper wedge (Kohn, 2008) in which the Himalayas are considered as a Coulomb wedge (Davis et al., 1983; Platt, 1993) undergoing overall shortening when the wedge was thinned and undergoing extension when the wedge was overthickened. In this model the contemporaneous shearing along the STDS and MCT is not required.

According to the above proposed models of exhumation most of the attention of the researchers was paid to the bounding shear zones and faults of the GHS. As a consequence during the last decades less attention has been put on the internal structure of the GHS and, moreover, faults and/or shear zones recognised within its core has been mainly regarded as out-of-sequence thrusts (see Mukherjee et al., 2011 for a review): Central Himalayas: Kalopani shear zone
(Vannay and Hodges, 1996) and Modi Khola shear zone (Hodges et al., 1996) and in Bhutan Himalayas: Kakhtang thrust (Daniel et al., 2003; Davidson et al., 1997) and Laya Thrust (Grujic et al., 2012).

However, recent works identified several ductile shear zones in the core of the GHS active before the activation of the MCT (Fig. 2): Sikkim (Rubatto et al., 2012); Eastern Nepal: High Himalayan Thrust (Goscombe et al., 2006; Imayama et al., 2012); Western Nepal: Tojiem shear zone (Carosi et al., 2007, 2010) and metamorphic discontinuity between upper and lower GHS (Larson et al., 2010; Yakymchuck and Godin, 2012).

These findings shed new light on the internal structure of the GHS and even on exhumation mechanisms of the unit itself. The shearing along shear zone within the GHS affected the metamorphic evolution of the two portions of the GHS separated by the shear zone itself causing its early exhumation, some Ma before the onset of MCT activity and, consequently, before the classical activation of extrusion/channel flow mechanisms of exhumation (Carosi et al., 2010).

In this view the occurrence, geometry, kinematics, extension and timing of shear zones in the core of the GHS is crucial in the discussion of the exhumation mechanisms.

Recent field works, in the remote region of Mugu-Karnali (Western Nepal), allowed to recognise one of the thickest shear zone within the GHS: the Mangri shear zone localized in its core, showing a thickness of $\sim 4 \mathrm{~km}$.

The aim of this paper is to describe the geometry, the kinematic, the $\mathrm{P}$ and $\mathrm{T}$ evolution of the Mangri shear zone in the crystalline rocks of the Central Himalayas, as well as its timing by U-Pb in-situ analyses on monazite, and to discuss the new results in the light of the most popular models for the exhumation of deeply seated metamorphic rocks in the Himalayas.

\section{Geological outline}

The Himalayan orogen (Fig. 2) is divided into four tectonic units from south to north: Sub-Himalayas molasses, Lesser Himalayan Sequence, Greater Himalayan Sequence and Tibetan Sedimentary Sequence. These units run parallel to the belt for more than $2400 \mathrm{~km}$ and are bounded by the Main Frontal Thrust, Main Boundary Thrust, Main Central Trust and South Tibetan Detachment (Hodges, 2000 and references therein).

The Lesser Himalayan Sequence (LHS) is made by impure quartzite, marble, phyllites, orthogneisses and metabasaltic rocks. These rocks are affected by a greenschist to lower amphibolite facies metamorphism (Hodges, 2000; Upreti, 1999). The LHS is subdivided in two

\section{(a) Channel flow}

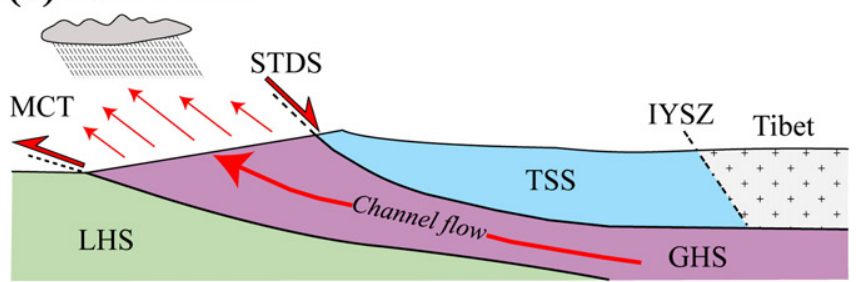

(c) Wedge insertion

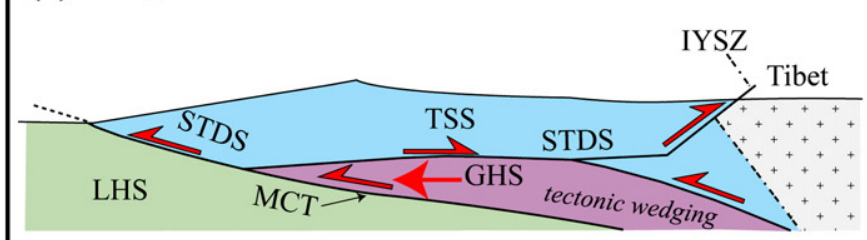

\section{(b) Wedge extrusion}

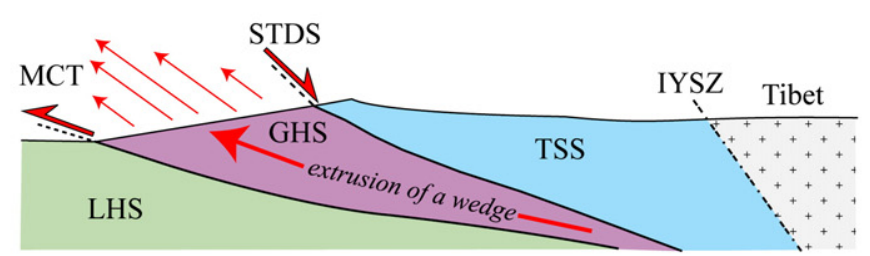

(d) Critical taper

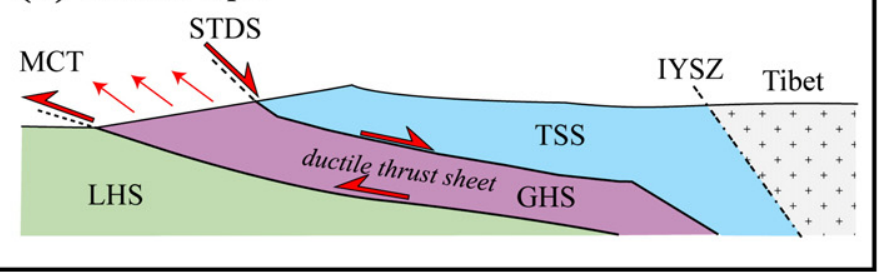

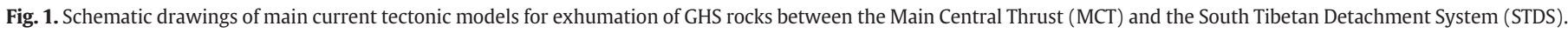

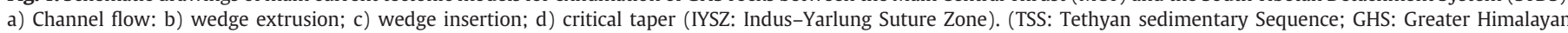
Sequence; LHS: Lesser Himalayan sequence). 


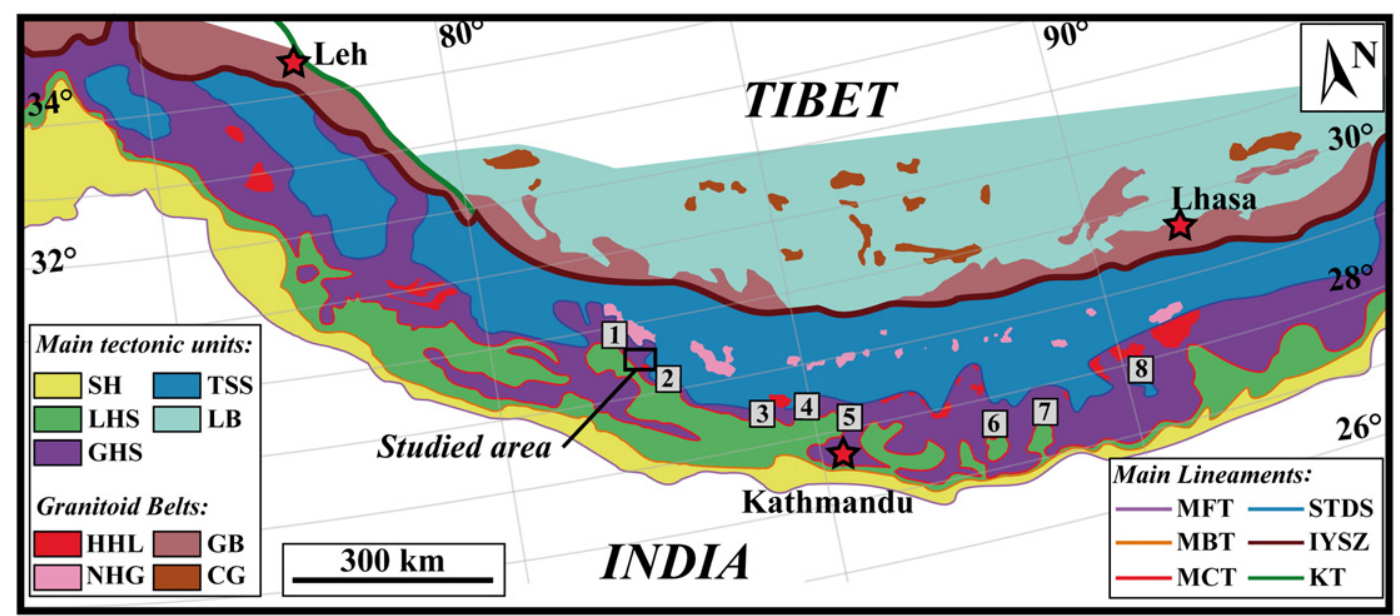

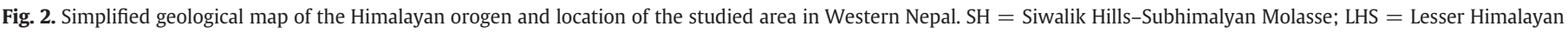

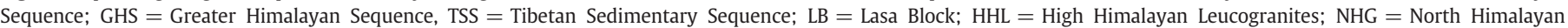

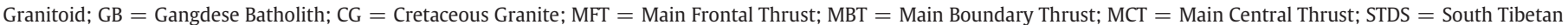

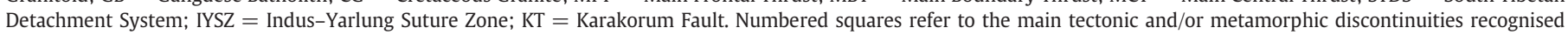

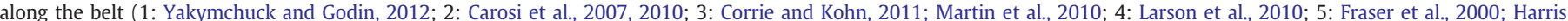

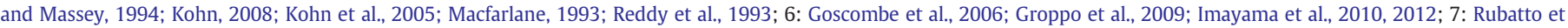
al., 2012; 8: Swapp and Hollister, 1991, see text for discussion).

Modified after Bertoldi et al. (2011).

groups separated by an unconformity. The lower group, called "Lower Lesser Himalaya", is made by sedimentary-volcaniclastic rocks and orthogneisses ranging in age from Paleo-Proterozoic to Meso-Proterozoic. The upper one, "Upper Lesser Himalaya” is made by carbonatic and associated quartzites and graphitic rich rocks of middle Proterozoic age and unconformably overlain by Upper Palaeozoic to Cenozoic rocks of Gondwanan affinity (Upreti, 1999).

The top-to-the-south Main Central thrust, dipping to the north, divides the lower LHS by the upper Greater Himalayan Sequence (Heim and Gansser, 1939; Hodges, 2000; Upreti, 1999).

The GHS is a $20-30 \mathrm{~km}$ thick sequence of medium- to high-grade metamorphic rocks, comprising upper amphibolite-grade schists, gneisses, migmatites and calc-silicates, that encompasses the areas with highest topographic relief. Most of the metasediments in the GHS are late Proterozoic to late Cambrian with lower Paleozoic intrusions. This unit reaches its minimum thickness of only $2-3 \mathrm{~km}$ in Western Nepal (Carosi et al., 2007). Oligo-Miocene leucogranites (Higher Himalayan Leucogranites: HHL) are associated with migmatitic gneisses (Visonà et al., 2012). These HHL are peraluminous granites of minimum melt composition that contain quartz + plagioclase $+\mathrm{K}$-feldspar + muscovite with variable amounts of biotite, garnet, cordierite and aluminosilicates, tourmaline and accessory apatite, monazite, zircon and beryl (Visonà and Lombardo, 2002; Visonà et al., 2012). Most leucogranites yield U-Pb monazite ages around 24-19 Ma (Searle and Godin, 2003 and references therein), with some younger leucogranites between 14 and $7 \mathrm{Ma}$ (Leech, 2008, and references therein; Kellett et al., 2010).

The GHS is separated from the overlying Tethyan Sedimentary Sequence (TSS) by a system of top-down-to-the-north shear zones and faults (STDS; Burchfiel et al., 1992; Burg et al., 1984; Caby et al., 1983; Carosi et al., 1998; Searle, 1999; Searle et al., 2003).

The TSS, which is north bounded by the Indus-Yarlung suture zone (Figs. 2, 3), is a folded sequence of marine sediments of Cambrian to Eocene age that were deposited on the northern Indian continental margin of the Tethyan Ocean (Antolín et al., 2011). The lower part of the TSS is made of low-grade metamorphic rocks derived from Cambro-Ordovician impure limestones, calcschists and quartzites (Carosi et al., 2002, 2007; Crouzet et al., 2007; Dunkl et al., 2011; Frank and Fuchs, 1970; Myrow et al., 2009).

A HHL covering an area on nearly $110 \mathrm{~km}^{2}$ with a thickness of $\sim 6 \mathrm{~km}$, named Bura Buri Leucogranite, has been recognised in between
Mugu-Karnali and Jumla village (Bertoldi et al., 2011). It is one of the few granites in the Himalayas cross-cutting both the HHC and the bottom of the TSS (Carosi et al., 2012). It is pretty undeformed and U-Pb ages from zircons and monazites extracted from the main granitic body and dikes intruded in the TSS point to an emplacement age at 23-24 Ma (Carosi et al., in press).

\subsection{Geology of the Mugu-Karnali transect}

The study transect provides an $\sim 30 \mathrm{~km}$ thick almost continuous section of the main tectonic units of the belt and it runs from the LHS through the MCT zone to the SW up to the contact with the TSS to the NE along the Mugu-Karnali and Puwa Khola valley (Fig. 4).

The lower part of the study transect, between Gamgadhi village and Rara lake (Fig. 4), is characterised by poorly deformed verylow-grade metamorphic quartzites, belonging to the Lesser Himalaya Sequence, showing primary sedimentary structures, such as planar and cross-bedding (Fig. 5a). Tight to isoclinal folds, affecting sedimentary bedding, trend N110 and plunge $40^{\circ}$ to the SE. The main foliation is a fine continuous foliation defined by Ms, Qz and Cal (abbreviations after Whitney and Evans, 2010) and strikes N130/N140 and dips to the NE. Phyllites, often very rich in carbonaceous material and dolomites and dolomitic limestones are also present. Widespread lenses of metabasites are made by Amp $+\mathrm{Chl}+\mathrm{Pl}+\mathrm{Ep}+\mathrm{Qz}+\mathrm{Opq}$ and show a heterogeneous continuous foliation.

The Main Central Thrust Zone (MCTZ) is located near Gamgadhi village (Fig. 4), and it affects the low-grade metamorphic quartzite of the Lesser Himalaya and phyllites, micaschists and orthogneisses, similar to the Ulleri orthogneiss (Le Fort and Rai, 1999), of the GHS.

Several zones of inverted metamorphic grade has been recognised and each metamorphic zone showing a thickness of $0.5-1 \mathrm{~km}$ from kyanite zone (Fig. 5b) in the upper part to chlorite zone in the lower one.

The main foliation, in the MCTZ, is a continuous foliation striking $\mathrm{N} 130$ and dipping to the $\mathrm{N}$ from 20 to $40^{\circ}$. Mineral lineation is well developed on the mylonitic foliation and trends mostly N170 and plunge $30-50^{\circ}$ to the $\mathrm{N}$.

Kinematic indicators develop at all scales and show a top-to-the-SW sense of shear. In the lower part of the MCTZ small-scale duplexes (Fig. 6), affected by low-angle synthetic faults, have been observed in 


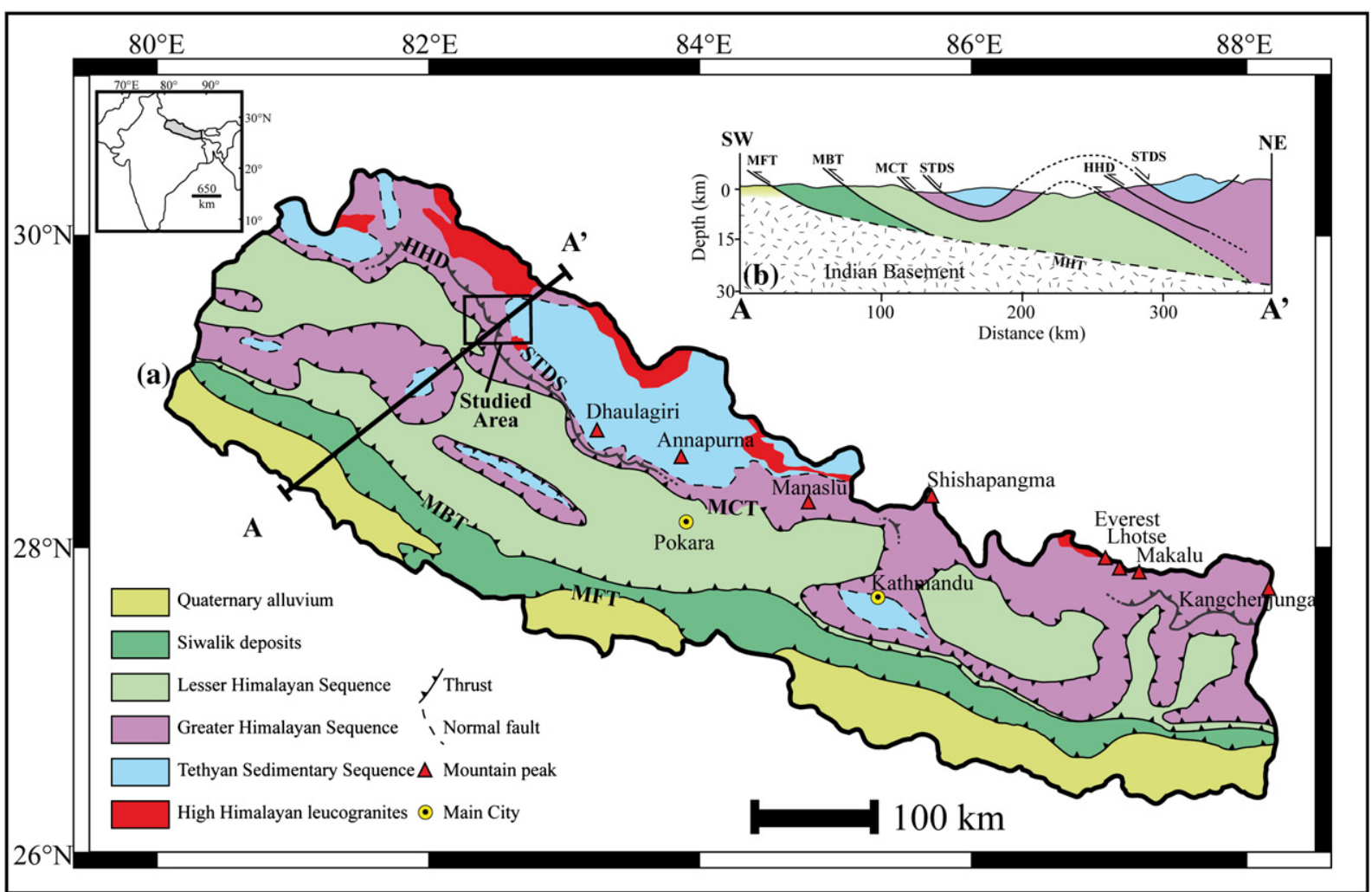

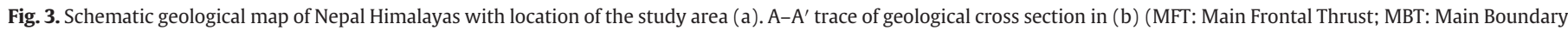
Thrust; MCT: Main Central Thrust; HHD: High Himalayan Discontinuity; STDS: South Tibetan Detachment System) (Modified after Corrie and Kohn, 2011).

quartzites. Sigmoidal quartz in phyllites is common and confirms the top-to-the-SW sense of shear. In micaschists and phyllites kinematic indicators are mainly represented by $\mathrm{C}-\mathrm{S}$ fabric and asymmetric rotated porhyroclasts.
Few kilometres above the upper limit of the inverted metamorphic sequence sillimanite bearing micaschist and migmatitic ortogneiss crop out. In the migmatites (Fig. 5c) sheath folds in quartzitic levels are well developed (Fig. 5d). After a few hundreds of metres we

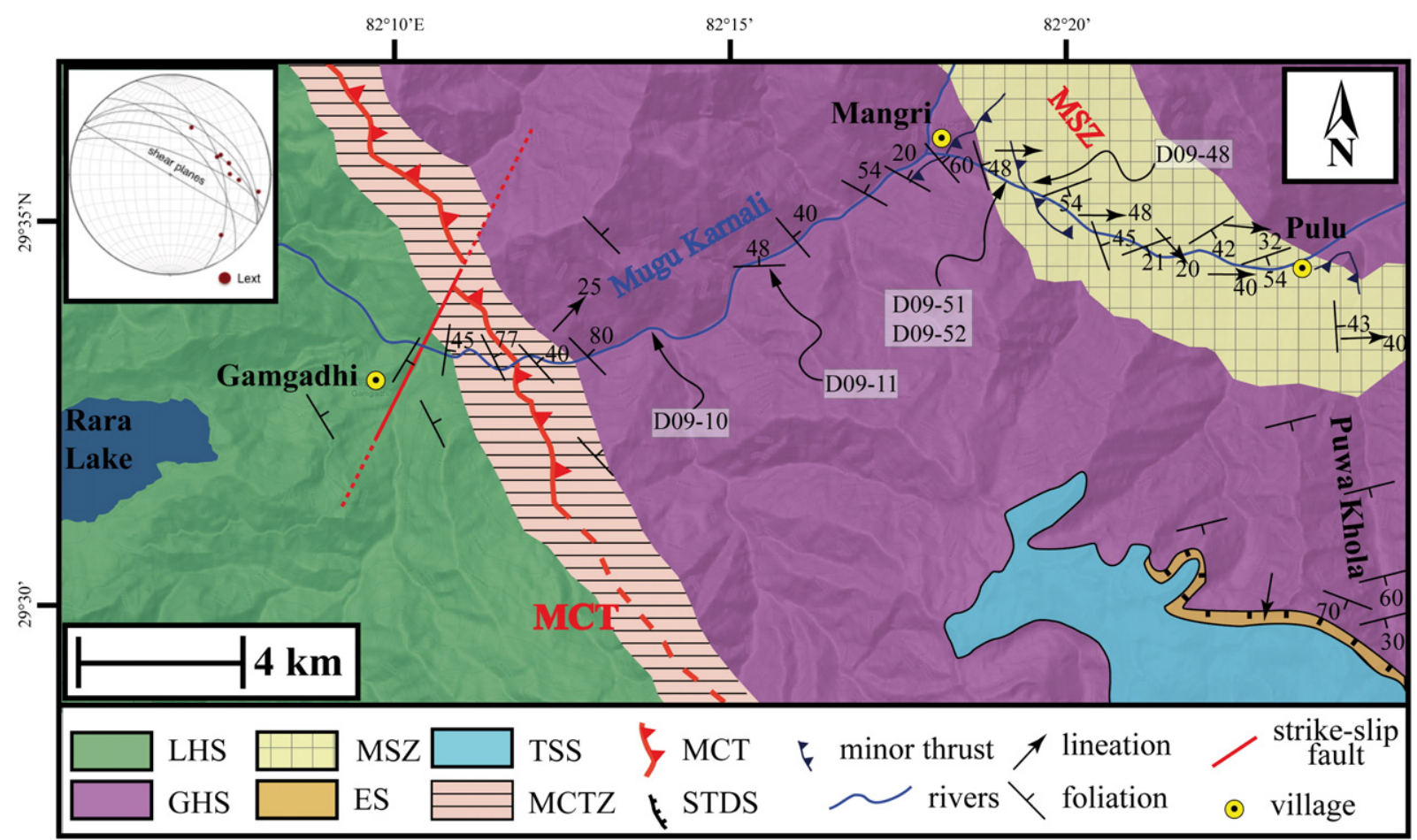

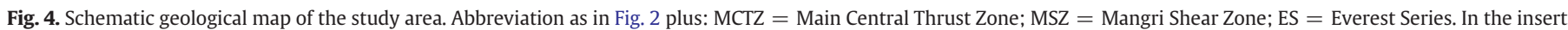
upper left, stereographic projection (lower hemisphere) of shear planes and related mineralogical lineations (Lext) of the Mangri Shear zone are represented. 

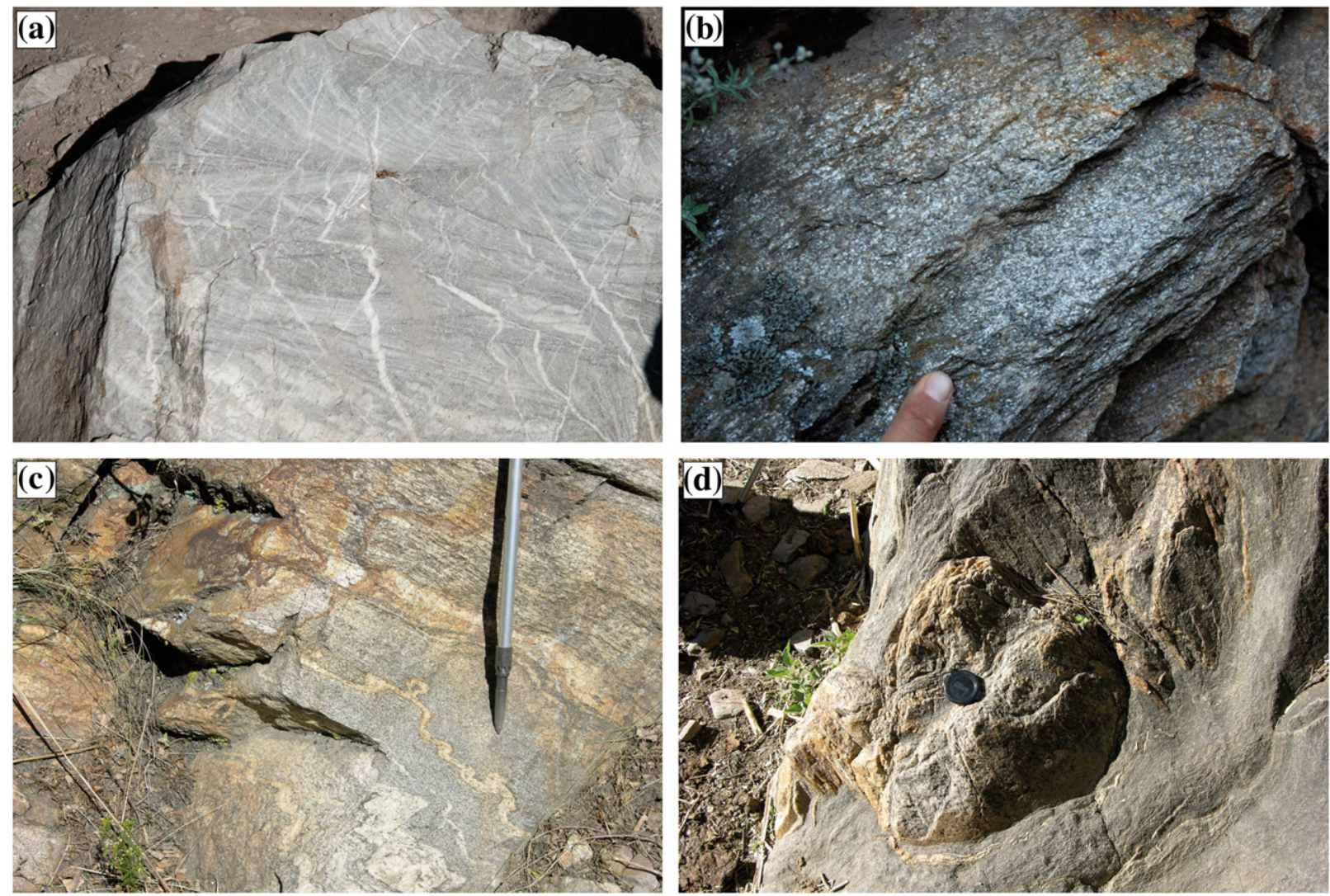

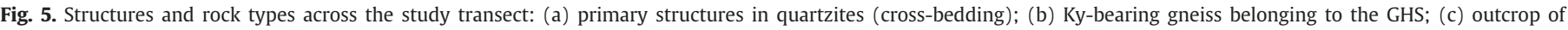
stromatic migmatites in the upper part of the GHS; and (d) sheath fold in migmatitic gneisses belonging to GHS.

encounter the first mylonites of the Mangri Shear Zone (Fig. 4), just after Mangri village (see Section 3).

In the upper drainage of the Puwa Khola valley (Fig. 4) a thin portion of metamorphic rocks belonging to the Everest Schists has been found in between the upper portion of the GHS and the low-grade metamorphics at the bottom of the Tibetan Sedimentary Sequence. The mineral assemblage is characterised by staurolite, kyanite (?), biotite and garnet with an HT-LP overprint by cordierite (rimming staurolite and garnet) and andalusite, as described by Jessup et al. (2008) in the Mt. Everest area.

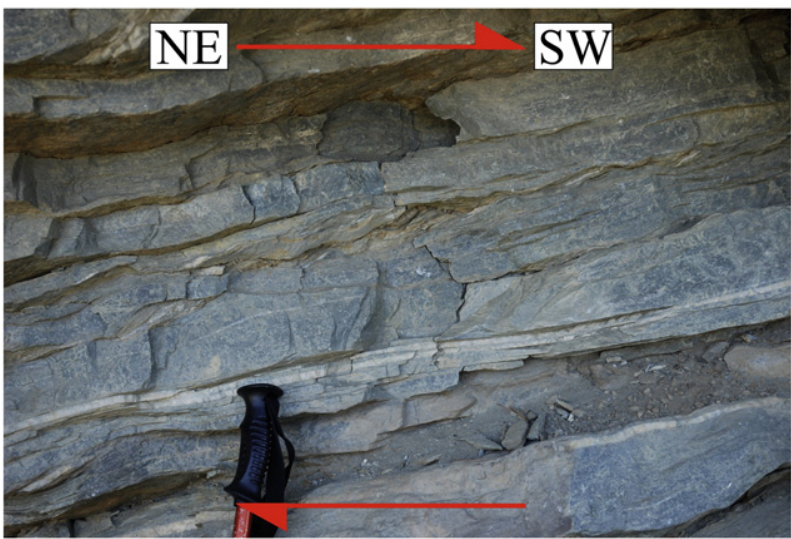

Fig. 6. Small-scale duplexes in the Main Central Thrust Zone in the phyllites of the Lesser Himalayan Sequence showing a top-to-the-SW sense of shear.
TSS is made by very-low to low-metamorphic grade rocks: metaconglomerates, biotite-bearing metasandstones and quartzites with well-preserved sedimentary structures (i.e. cross-bedding in calcareous sandstones). TSS rocks are affected by ENE-WSW trending folds with a low-grade penetrative axial planar foliation defined by $\mathrm{Chl}+\mathrm{Cal}+\mathrm{Qz}$. The main foliation varies from a continuous to a spaced disjunctive cleavage marked by biotite, muscovite, rare actinolitic hornblende, quartz, calcite and epidote. This foliation is frequently overgrown by random and coarser post-tectonic biotite grains.

A network of leucogranite dykes and sills occurs in the Tethyan rocks up to nearly $5500 \mathrm{~m}$ of altitude. Some of them are deformed and boudinaged along the main foliation whereas others are undeformed and cross-cut the main fabric of the host rocks.

After the pass from Puwa Khola valley and the main peaks dividing Mugu-Karnali drainage from Jumla area we encounter the upper portion of the Bura Buri granite (Bertoldi et al., 2011; Carosi et al., in press) intruded in the lower part of the TSS and cross-cutting upright folds.

\section{Mangri shear zone}

The Mangri shear zone affects paragneiss (Fig. 7a), micaschist, migmatitic gneiss and orthogneiss (Fig. 7b) showing a thickness of nearly $4 \mathrm{~km}$ exhibiting fault rocks from protomylonites to mylonites with heterogeneous deformation.

Mylonitic foliation in the shear zone is concordant with the prominent foliation in the wall rocks and strikes N130-N150 and dips from $20^{\circ}$ to $50^{\circ}$ towards the NE (inset in Fig. 4). Mineral lineation trends from 90 to $140^{\circ}$ and plunges $30-40^{\circ}$ to the E and SE (inset in Fig. 4). Mylonitic foliation is affected by later open folds causing change of the strike and dip. 

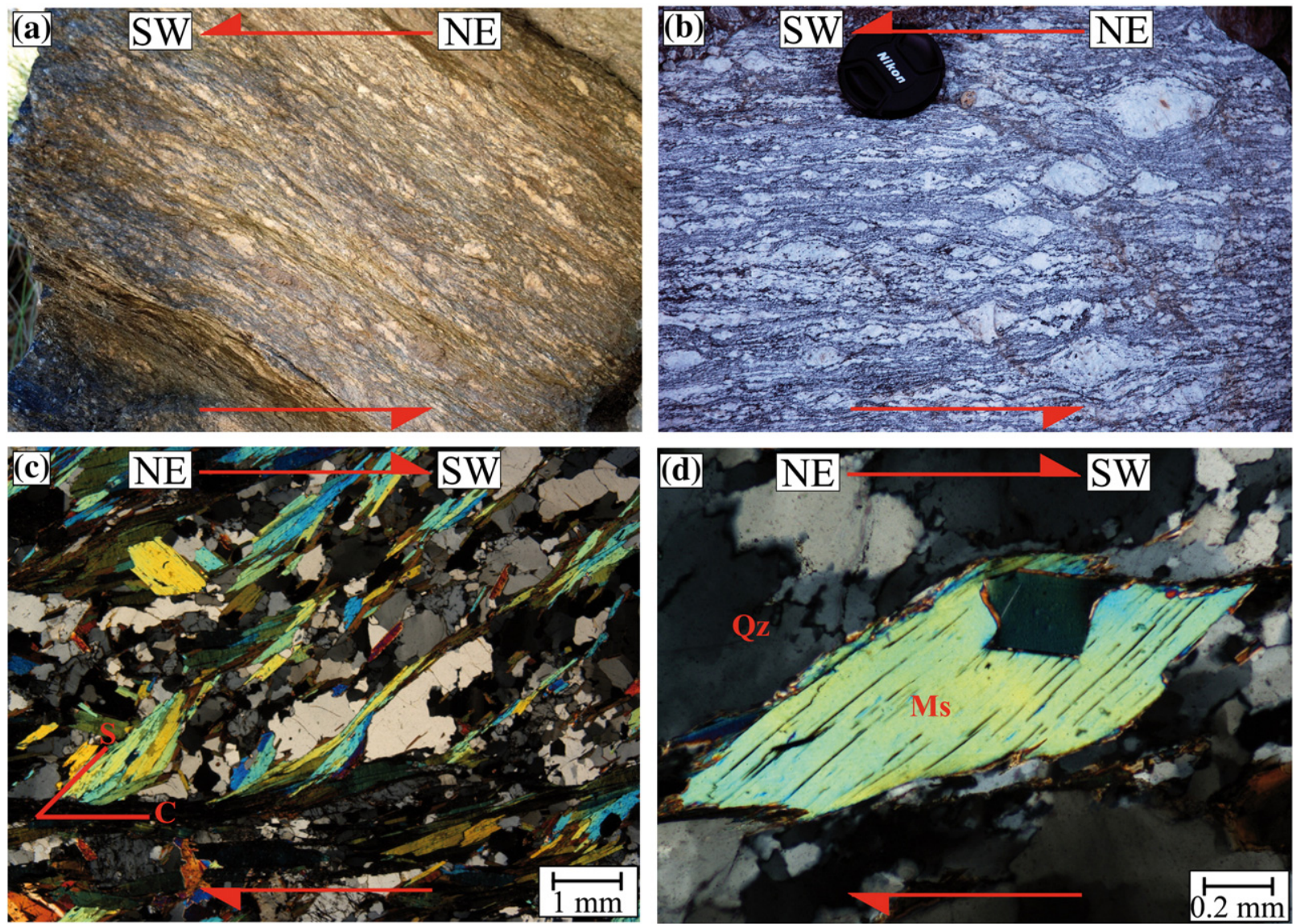

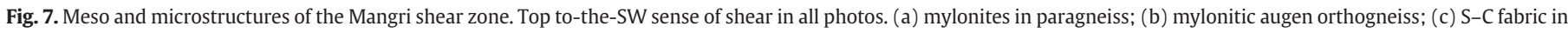
thin section of the Mangri shear zone mylonites; and (d) micafish.

Kinematic indicators, at the outcrop scale are represented by S-C-C' fabric, rotated $\sigma$-type porhyroclasts (mainly quartz and feldspar crystals), minor asymmetric folds and deflected foliation (Fig. 7a-b). Kinematic indicators at the microscale, observed on sections cut parallel to the mineral lineation and perpendicular to the main foliation, are represented by well-developed mica-fish (Groups 1 \& 4 sensu Passchier and Trouw, 2005) and S-C-C' fabric (Fig. 7c and d).

The mylonitic foliation can be classified as an anastomosing disjunctive foliation. Along the foliation syn-kinematic recrystallisation of Ms, Bt, Sil, Qz, Opq and Tur has been observed. The foliation wraps around Grt, Pl and Tur porphyroclasts.

In the granoblastic domain (Q-Domain) quartz and plagioclase show lobate grain boundaries. Quartz shows undulose extinction, chessboard subgrains (Fig. 8) and presents pinning microstructures. Plagioclase shows flame twinning, is fractured locally and rarely myrmekites developed. Microstructures highlight a regime of dynamic recrystallisation compatible with T higher than $650{ }^{\circ} \mathrm{C}$ (Passchier and Trouw, 2005) in agreement with the recrystallisation of sillimanite along the mylonitic foliation.

\section{Mineral chemistry, major element zoning and P-T estimates}

\subsection{Study samples}

Five samples have been selected from different structural positions: samples D09-52, D09-51 and D09-48 came from the Mangri shear zone's hanging-wall, whereas samples D09-10 and D09-11 are from its footwall. Geothermobarometric and geochronological analyses have been performed on samples from both hanging-wall and footwall of the shear zone (Table 1).

Sample D09-52 is a mylonitic paragneiss with mineral assemblage of Grt, Bt, Sil, Ms, Pl and Qz. The main foliation (Sp) is characterised by an S-C fabric with dynamic recrystallisation of Sil + Bt. Late retrograde $\mathrm{Chl}$ is locally found near garnet edges and along foliation planes. Sample

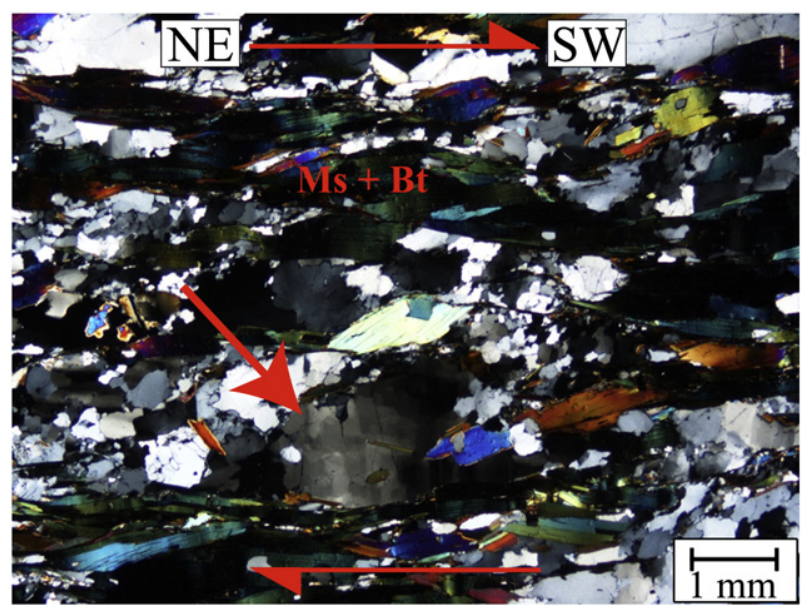

Fig. 8. Chessboard structure in quartz (red arrow) pointing out a high $\mathrm{T}$ regime of deformation. 
Table 1

Summary of the studied samples and of the methods applied for each sample.

\begin{tabular}{lllll}
\hline Sample & $\begin{array}{l}\text { Structural } \\
\text { position }\end{array}$ & Paragenesis & $\begin{array}{l}\text { P-T } \\
\text { estimates }\end{array}$ & $\begin{array}{l}\text { Mnz } \\
\text { geochronology }\end{array}$ \\
\hline D09-10 & Footwall & Grt-St-Bt-Ms-Pl-Qz \pm Ky & X & $\mathrm{X}$ \\
D09-11 & Footwall & Grt-Ky-Bt-Ms-Pl-Qz & $\mathrm{X}$ & \\
D09-48 & Hanging-wall & Bt-Ms-Pl-Qtz & & $\mathrm{X}$ \\
D09-51 & Hanging-wall & Grt-Bt-Ms-Pl-Qz & $\mathrm{X}$ & $\mathrm{X}$ \\
D09-52 & Hanging-wall & Grt-Sil-Bt-Ms-Pl-Qz & $\mathrm{X}$ & $\mathrm{X}$ \\
\hline
\end{tabular}

D09-51 is a mylonitic paragneiss with an S-C fabric and the same mineralogy of the D09-52 sample, but lacking of Sil, probably reflecting a minor aluminous content of the original pelite. Sample D09-48 is a mylonitic micaschist with mineral assemblage consisting of Bt, Ms, Pl and Qz. Garnet in samples D09-52 and D09-51 is pecilitic, with inclusions of $\mathrm{Bt}, \mathrm{Pl}, \mathrm{Qz}$ and Ms. Locally, the inclusions are aligned and define an internal foliation ( $\mathrm{Si}$ ) discordant with the external one (Sp). An internal foliation, defined by $\mathrm{Gr}, \mathrm{Bt}$ and rare $\mathrm{Qz}+\mathrm{Pl}$ inclusions discordant with the main foliation (Sp), occurs also within Ms porphyroclasts that locally show deformation of the cleavage planes. Sample D09-48 presents a foliation marked by Ms and Bt, alternating to granoblastic quartz-feldspatic layers. An older foliation is marked by flakes of Ms and Bt crystals at high-angle with respect to the main foliation. Common accessories in the matrix are Tur, Gr, Ilm, Ap, Zrn, Mnz and \pm Xtm.

Sample D09-10, from the footwall of the MSZ, is a Grt, St, Bt, Ms, $\mathrm{Qz}$ and \pm Ky micaschist. The main foliation is defined by Ms and $\mathrm{Bt}$ growth, with rare Ky often showing kinking. Sp foliation can be classified as spaced anastomosing disjunctive schistosity. Grt has an inclusion rich core (of Bt, Ms, Chl, Pl, Gr, Rt-Ilm, Qz), defining an Si and an inclusion free rim. St has also an Si made with the same mineral assemblage plus Tur, but sometimes this internal foliation is in continuity with the external one. In this view Grt rim and St growth are pre- to syn-kinematic with respect to the main foliation. It is also worth to note that Rt inclusions are rimmed by Ilm. Common accessories in the matrix are Tur, Gr, Zrn, Mnz, Ilm (rarely with a Rt core), Xtm and Ap. Chlorite and sericite have been rarely found near rims of both garnet and kyanite.

Sample D09-11 is a Grt + Ky micaschist. Grt is present as large (up to $2 \mathrm{~cm}$ in diameter) porphyroblast with a folded internal foliation ( $\mathrm{Si}$ ) defined by the orientation of $\mathrm{Bt}, \mathrm{Qz}, \mathrm{Rt}$ and Aln, discordant with respect to the main external foliation. The main foliation is defined by the alternation of lepidoblastic layers made by Ms, Bt and Ky with granoblastic layers of $\mathrm{Pl}$ and $\mathrm{Qz}$ and is classified as an anastomosing disjunctive schistosity. Within Grt rims, tiny crystals of St are found. Ky is present as matrix porphyroblast along the main foliation (Sp) and frequently contains Rt inclusions. Common accessories are Tur, Ap, Aln, Zrn and Ilm, the latter mainly occurs as rim on Rt. Locally Ttn rims on Ilm are observed, in association with retrograde Chl within pressure shadows near the Grt.

\subsection{Mineral chemistry and major element zoning}

Quantitative chemical analyses of minerals (i.e. Grt, St, Ms, Bt, Pl, Ilm, Mnz) were performed with JEOL 8200 Super Probe equipped with five WDS at the Earth Sciences Department of Milan University. Analysis were performed using an accelerating voltage of $15 \mathrm{kV}$ and $5 \mathrm{nA}$ beam current and a beam size of $\sim 1 \mu \mathrm{m}$. Staurolite analyses were carried out in a separate analytical session, without $\mathrm{Na}$, in order to avoid $\mathrm{Zn}-\mathrm{Na}$ interference. Defocused beam of $\sim 5 \mu \mathrm{m}$ were used for micas. Raw data were corrected applying a ZAF correction.

Monazite were analysed following the method suggested by Pyle et al. (2002). Pure oxide, natural and synthetic minerals were used for calibration. Multi-point analyses and/or mineral transects were made in order to detect zoning in minerals. Representative analyses for major and accessory phases are reported in Tables 2a, $2 \mathrm{~b}$ and 3.

\subsubsection{Hanging-wall rocks}

Samples from the shear zone hanging-wall (D09-52 and D09-51) contain garnet with less evident chemical zoning from core to rim with respect to the samples from the footwall probably due to diffusion processes at temperature peak. Garnet in sample D09-51 shows a decrease of XMn and $\mathrm{Fe} /(\mathrm{Fe}+\mathrm{Mg}$ ) ratio (hereafter referred as $\mathrm{Fe \#}$ ) from core ( 0.08 and 0.90$)$ to rim ( 0.05 and 0.88 ), a quite constant XFe between 0.78 and 0.79 and XCa (between 0.05 and 0.08 ) and an increase in XMg from 0.09 to 0.10 . The outermost rims show a sharp increase of XMn ( 0.12) and Fe\# ( 0.91), confirming the occurrence of retrograde net transfer reactions (Kohn and Spear, 2000). The same pattern is present in D09-52 garnet, where XMn decreases from 0.11 from core position to 0.03 near rim and Fe\# from 0.90 to 0.85 . XCa varies from quite constant $(<0.05)$ to a decreasing trend $(0.09$ to 0.04$)$ in larger grains. Also in this sample it is evident that the outermost rims are affected by retrograde net transfer reactions as outlined by increase of XMn (0.12) and XFe (0.91).

In both samples, plagioclase, occurring as garnet inclusions, has an anorthitic composition higher than that of matrix plagioclase $\left(\mathrm{An}_{27-25}\right.$ to $\mathrm{An}_{20-18}$ ). Biotite chemistry shows a regular variation of $\mathrm{Ti}$ and $\mathrm{XMg}$ according to textural position of minerals in both samples. Grains within garnet have a minor $\mathrm{Ti}$ and a larger XMg contents with respect to matrix grains. Ti varies from $0.10-0.12$ a.p.f.u. to $0.15-0.18$ a.p.f.u. while XMg decreases from 0.41 to 0.32 in sample D09-51; in sample D09-52 Ti increases from 0.09-0.10 a.p.f.u. to 0.15-0.18 and XMg decreases from $0.45-0.50$ to $0.36-0.38$.

Muscovite does not show a clear correlation between chemistry and textural position like biotites, since Ms inclusions have $\mathrm{Si}^{4+}$ a.p.f.u between 3.09 and 3.15 overlapping the quite constant $\mathrm{Si}^{4+}$ content of Ms along the foliation planes (3.10-3.12 a.p.f.u). The Ms porphyroclasts, occurring in both samples, show a chemical zoning characterised by a decrease of silica from core to $\operatorname{rim}\left(\mathrm{Si}^{4+}\right.$ from 3.25 to 3.12 a.p.f.u., see Table $2 a$ ). It is interesting to note that the $\mathrm{Si}^{4+}$ contents of the rims are very close to those of micas along the foliation planes, while core compositions show a higher $\mathrm{Si}^{4+}$ content.

\subsubsection{Footwall rocks}

Garnet shows a decrease of Mn, Ca and Fe\# and an increase of Mg and Fe from core to rim.

D09-10 shows a clear core to rim zoning with XMn and XCa decreasing from core $(\mathrm{XMn} \sim 0.12, \mathrm{XCa} \sim 0.18$ ) to $\operatorname{rim}(\mathrm{XMn} \sim 0.01, \mathrm{XCa} \sim 0.06$ ) balanced by an increase of $\mathrm{Mg}(\mathrm{XMg} \sim 0.04$ vs $\mathrm{XMg} \sim 0.14)$ and $\mathrm{Fe}$ (XFe $\sim 0.66$ vs XFe $\sim 0.80$ ). Fe\# ratio decrease from core (Fe\# $\sim 0.95$ ) to rim (Fe\# 85). Garnets from sample D09-11 have a quite constant core to rim composition of XMn $(\sim 0.01)$ and XCa $(\sim 0.15)$, a slight decrease of XFe ( 0.67 to 0.64 ) and Fe\# (0.79 to 0.76 ), while XMg increases ( 0.18 to 0.20 ) rimward. The outermost garnet rim is affected by retrograde reactions as suggested by upturns of XMn $(\sim 0.02)$ and of XFe (0.68) as highlighted by Kohn and Spear (2000).

Staurolite porphyroblast in sample D09-10 presents a low ZnO concentration (below $0.5 \mathrm{wt} . \%$ ) and shows an increase of XFe from core to rim (0.80 to 0.83 ), coupled with a decrease of $\mathrm{Mg}$ and $\mathrm{Zn}$ from core $(\mathrm{XMg} 0.18, \mathrm{XZn} \sim 0.02)$ to $\operatorname{rim}(\mathrm{XMg} \sim 0.16, \mathrm{XZn} \sim 0.01)$ probably related to a growth zoning. Staurolite in sample D09-11 is present only as tiny inclusions in garnet and it has slightly higher $\mathrm{ZnO}$ content ( $>1 \mathrm{wt} . \%$ ).

Plagioclase inclusions within garnet are present only in sample D09-10 and show a higher anorthitic content $\left(\mathrm{An}_{40}-\mathrm{An}_{30}\right)$ than the plagioclase in the matrix $\left(\mathrm{An}_{10}\right)$ which is quite homogeneous. This trend is typical of plagioclase coexisting with the growth of garnet as these two minerals have the higher calcium content (Spear et al., 1991). In sample D09-11 plagioclase inclusions within garnet are lacking. Matrix plagioclase is homogeneous in composition with a much higher anorthitic composition $\left(\mathrm{An}_{80}-\mathrm{An}_{70}\right)$ with respect to the plagioclase from the D09-10 sample. This high anorthitic content is probably due to a higher Ca bulk composition of the protolith as also 
Table 2a

Electron Microprobe Analyses (EMPA) mineral chemistry of hanging-wall samples (D09-51 and D09-52).

\begin{tabular}{|c|c|c|c|c|c|c|c|c|c|c|c|c|c|c|c|c|c|c|}
\hline \multirow[t]{2}{*}{ Mineral } & \multirow{2}{*}{$\frac{\text { D09-51 }}{\text { Grt core }}$} & \multirow{2}{*}{$\frac{\text { D09-51 }}{\text { Grt near rim }}$} & \multirow{2}{*}{$\frac{\mathrm{D} 09-51}{\mathrm{Bt} \text { in Grt }}$} & \multirow{2}{*}{$\frac{\text { D09-51 }}{\text { Bt matrix }}$} & \multirow{2}{*}{$\frac{\mathrm{D} 09-51}{\mathrm{Ms} \text { in Grt }}$} & \multirow{2}{*}{$\frac{\text { D09-51 }}{\text { Ms matrix }}$} & \multirow{2}{*}{$\frac{\text { D09-51 }}{\text { Ms P.clast }}$} & \multirow{2}{*}{$\frac{\mathrm{D} 09-51}{\mathrm{Pl} \text { in Grt }}$} & \multirow{2}{*}{$\frac{\text { D09-51 }}{\text { Pl matrix }}$} & \multirow{2}{*}{$\frac{\text { D09-52 }}{\text { Grt core }}$} & \multirow{2}{*}{$\frac{\text { D09-52 }}{\text { Grt near rim }}$} & \multirow{2}{*}{$\frac{\mathrm{D} 09-52}{\mathrm{Bt} \text { in } \mathrm{Grt}}$} & \multirow{2}{*}{$\frac{\text { D09-52 }}{\text { Bt matrix }}$} & \multirow{2}{*}{$\frac{\mathrm{D} 09-52}{\mathrm{Ms} \text { in Grt }}$} & \multirow{2}{*}{$\frac{\text { D09-52 }}{\text { Ms matrix }}$} & \multirow{2}{*}{$\frac{\text { D09-52 }}{\text { Ms P.clast }}$} & \multirow{2}{*}{$\frac{\mathrm{D} 09-52}{\mathrm{Pl} \text { in Grt }}$} & \multirow{2}{*}{$\frac{\text { D09-52 }}{\text { Pl matrix }}$} \\
\hline & & & & & & & & & & & & & & & & & & \\
\hline \multicolumn{19}{|l|}{$w t \%$} \\
\hline $\mathrm{SiO}_{2}$ & 37.90 & 37.96 & 36.56 & 34.82 & 47.60 & 47.52 & 49.19 & 62.28 & 62.24 & 37.15 & 38.14 & 36.44 & 35.82 & 48.36 & 47.9 & 50.08 & 63.89 & 64.80 \\
\hline $\mathrm{TiO}_{2}$ & 0.03 & 0.03 & 1.73 & 3.07 & 0.43 & 0.65 & 1.20 & - & - & 0.03 & 0.03 & 1.24 & 3.2 & 0.56 & 0.73 & 0.96 & - & - \\
\hline $\mathrm{Al}_{2} \mathrm{O}_{3}$ & 20.60 & 20.52 & 19.52 & 19.01 & 35.17 & 34.00 & 32.17 & 24.83 & 22.48 & 21.36 & 20.71 & 19.98 & 18.92 & 35.52 & 35.88 & 33.05 & 22.91 & 23.15 \\
\hline $\mathrm{Cr}_{2} \mathrm{O}_{3}$ & 0.04 & 0.00 & 0.00 & 0.01 & 0.06 & 0.03 & 0.00 & - & - & 0.00 & 0.00 & 0.05 & 0.03 & 0.00 & 0.01 & 0.00 & - & - \\
\hline $\mathrm{FeO}$ & 35.44 & 36.05 & 21.40 & 23.91 & 1.52 & 1.48 & 1.80 & 0.17 & 0.08 & 35.2 & 36.43 & 18.74 & 22.41 & 1.19 & 1.13 & 1.62 & 0.18 & 0.03 \\
\hline $\mathrm{ZnO}$ & - & - & - & - & - & - & - & - & - & - & - & - & - & - & - & - & - & - \\
\hline $\mathrm{MnO}$ & 3.46 & 2.14 & 0.13 & 0.13 & 0.03 & 0.01 & 0.03 & - & - & 4.97 & 1.39 & 0.07 & 0.08 & 0.07 & 0.05 & 0.04 & - & - \\
\hline MgO & 2.19 & 2.64 & 8.41 & 6.27 & 0.72 & 0.55 & 1.02 & - & - & 1.88 & 3.51 & 9.62 & 6.98 & 0.61 & 0.49 & 1.04 & - & - \\
\hline $\mathrm{CaO}$ & 1.92 & 2.39 & 0.03 & 0.02 & 0.01 & 0.01 & 0.00 & 4.90 & 4.10 & 1.09 & 1.69 & 0.07 & 0.01 & 0.03 & 0.01 & 0.03 & 4.12 & 4.17 \\
\hline $\mathrm{Na}_{2} \mathrm{O}$ & - & - & 0.22 & 0.11 & 0.53 & 0.62 & 0.48 & 8.44 & 8.89 & - & - & 0.19 & 0.36 & 0.83 & 0.93 & 0.73 & 9.05 & 8.98 \\
\hline $\mathrm{K}_{2} \mathrm{O}$ & - & - & 9.17 & 9.42 & 9.41 & 9.75 & 9.31 & 0.17 & 0.22 & - & - & 8.61 & 8.65 & 9.29 & 9.03 & 8.75 & 0.08 & 0.09 \\
\hline Tot. & 101.58 & 101.73 & 97.86 & 96.77 & 95.49 & 94.63 & 95.19 & 100.79 & 98.01 & 101.68 & 101.90 & 95.01 & 96.46 & 96.47 & 96.16 & 96.30 & 100.23 & 101.23 \\
\hline $\mathrm{O}$ basis & 12 & 12 & 11 & 11 & 11 & 11 & 11 & 32 & 32 & 12 & 12 & 11 & 11 & 11 & 11 & 11 & 32 & 32 \\
\hline $\mathrm{Si}$ & 3.03 & 3.02 & 2.74 & 2.67 & 3.14 & 3.17 & 3.25 & 10.94 & 11.22 & 2.97 & 3.01 & 2.75 & 2.72 & 3.15 & 3.12 & 3.25 & 11.05 & 11.28 \\
\hline $\mathrm{Al}^{\mathrm{IV}}$ & 0.00 & 0.00 & 1.26 & 1.33 & 0.87 & 0.83 & 0.75 & 5.14 & 4.78 & 0.03 & 0.00 & 1.25 & 1.28 & 0.85 & 0.88 & 0.75 & 4.83 & 4.75 \\
\hline $\mathrm{Al}^{\mathrm{VI}}$ & 1.94 & 1.92 & 0.46 & 0.39 & 1.87 & 1.84 & 1.76 & - & - & 1.99 & 1.93 & 0.52 & 0.41 & 1.87 & 1.88 & 1.79 & - & - \\
\hline $\mathrm{Ti}$ & 0.00 & 0.00 & 0.10 & 0.18 & 0.02 & 0.03 & 0.06 & - & - & 0.00 & 0.00 & 0.07 & 0.18 & 0.03 & 0.04 & 0.05 & - & - \\
\hline $\mathrm{Cr}$ & 0.00 & 0.00 & 0.00 & 0.00 & 0.00 & 0.00 & 0.00 & - & - & 0.00 & 0.00 & 0.00 & 0.00 & 0.00 & 0.00 & 0.00 & - & - \\
\hline $\mathrm{Fe}^{3+}$ & 0.00 & 0.04 & - & - & - & - & - & 0.02 & 0.01 & 0.04 & 0.04 & - & - & - & - & - & 0.05 & 0.00 \\
\hline $\mathrm{Fe}^{2+}$ & 2.37 & 2.36 & 1.34 & 1.53 & 0.08 & 0.08 & 0.1 & - & - & 2.32 & 2.37 & 1.18 & 1.42 & 0.07 & 0.06 & 0.09 & - & - \\
\hline $\mathrm{Zn}$ & - & - & - & - & - & - & - & - & - & - & - & - & - & - & - & - & - & - \\
\hline $\mathrm{Mn}$ & 0.23 & 0.14 & 0.01 & 0.01 & 0.00 & 0.00 & 0.00 & - & - & 0.34 & 0.09 & 0.01 & 0.01 & 0.00 & 0.00 & 0.00 & - & - \\
\hline $\mathrm{Mg}$ & 0.26 & 0.31 & 0.94 & 0.72 & 0.07 & 0.06 & 0.10 & - & - & 0.22 & 0.41 & 1.08 & 0.79 & 0.06 & 0.05 & 0.10 & - & - \\
\hline $\mathrm{Ca}$ & 0.16 & 0.2 & 0.00 & 0.00 & 0.00 & 0.00 & 0.00 & 0.92 & 0.79 & 0.09 & 0.14 & 0.01 & 0.00 & 0.00 & 0.00 & 0.00 & 0.97 & 0.78 \\
\hline $\mathrm{Na}$ & - & - & 0.03 & 0.02 & 0.07 & 0.08 & 0.06 & 2.87 & 3.11 & - & - & 0.03 & 0.05 & 0.11 & 0.12 & 0.09 & 2.89 & 3.03 \\
\hline K & - & - & 0.88 & 0.92 & 0.79 & 0.83 & 0.79 & 0.04 & 0.05 & - & - & 0.83 & 0.84 & 0.77 & 0.75 & 0.73 & 0.01 & 0.02 \\
\hline Tot. & 8.00 & 8.00 & 7.76 & 7.76 & 6.91 & 6.92 & 6.86 & 19.93 & 19.96 & 8.00 & 8.00 & 7.72 & 7.70 & 6.90 & 6.90 & 6.84 & 19.90 & 19.86 \\
\hline
\end{tabular}


Table 2b

Electron Microprobe Analyses (EMPA) mineral chemistry of footwall samples (D09-10 and D09-11).

\begin{tabular}{|c|c|c|c|c|c|c|c|c|c|c|c|c|c|c|c|c|c|c|}
\hline \multirow[t]{2}{*}{ Mineral } & \multirow{2}{*}{$\frac{\text { D09-10 }}{\text { Grt core }}$} & \multirow{2}{*}{$\frac{\text { D09-10 }}{\text { Grt near rim }}$} & \multirow{2}{*}{$\frac{\mathrm{D} 09-10}{\mathrm{Bt} \text { in Grt }}$} & \multirow{2}{*}{$\frac{\text { D09-10 }}{\text { Bt matrix }}$} & \multirow{2}{*}{$\frac{\mathrm{D} 09-10}{\mathrm{Ms} \text { in Grt }}$} & \multirow{2}{*}{$\frac{\text { D09-10 }}{\text { Ms matrix }}$} & \multirow{2}{*}{$\frac{\mathrm{D} 09-10}{\mathrm{Pl} \text { in Grt }}$} & \multirow{2}{*}{$\frac{\text { D09-10 }}{\text { Pl matrix }}$} & \multirow{2}{*}{$\frac{\text { D09-10 }}{\text { St core }}$} & \multirow{2}{*}{$\frac{\text { D09-10 }}{\text { St rim }}$} & \multirow{2}{*}{$\frac{\text { D09-11 }}{\text { Grt core }}$} & \multirow{2}{*}{$\frac{\text { D09-11 }}{\text { Grt near rim }}$} & \multirow{2}{*}{$\frac{\mathrm{D} 09-11}{\mathrm{Bt} \text { in Grt }}$} & \multirow{2}{*}{$\frac{\text { D09-11 }}{\text { Bt matrix }}$} & \multirow{2}{*}{$\frac{\text { D09-11 }}{\mathrm{Ms} \text { in Grt }}$} & \multirow{2}{*}{$\frac{\text { D09-11 }}{\text { Ms matrix }}$} & \multirow{2}{*}{$\frac{\text { D09-11 }}{\text { Pl matrix }}$} & \multirow{2}{*}{$\frac{\mathrm{D} 09-11}{\mathrm{St} \text { in Grt }}$} \\
\hline & & & & & & & & & & & & & & & & & & \\
\hline$w t . \%$ & & & & & & & & & & & & & & & & & & \\
\hline $\mathrm{SiO}_{2}$ & 37.68 & 37.74 & 35.78 & 36.24 & 47.13 & 47.77 & 61.19 & 63.28 & 28.00 & 28.20 & 38.04 & 38.49 & 36.86 & 35.49 & 44.63 & 47.87 & 50.63 & 27.60 \\
\hline $\mathrm{TiO}_{2}$ & 0.05 & 0.06 & 1.02 & 0.83 & 0.48 & 0.45 & - & - & 0.69 & 0.54 & 0.08 & 0.01 & 2.10 & 2.50 & 0.70 & 0.35 & - & 0.61 \\
\hline $\mathrm{Al}_{2} \mathrm{O}_{3}$ & 20.22 & 20.78 & 17.68 & 19.29 & 36.89 & 36.09 & 23.77 & 22.32 & 52.11 & 52.66 & 22.34 & 22.59 & 19.43 & 20.12 & 34.98 & 32.14 & 32.93 & 54.54 \\
\hline $\mathrm{Cr}_{2} \mathrm{O}_{3}$ & 0.00 & 0.03 & 0.00 & 0.01 & 0.04 & 0.10 & - & - & 0.00 & 0.01 & 0.16 & 0.24 & 0.17 & 0.20 & 0.31 & 0.38 & - & 0.55 \\
\hline $\mathrm{FeO}$ & 29.98 & 36.78 & 23.69 & 21.92 & 0.95 & 0.77 & 0.42 & 0.04 & 13.81 & 14.09 & 30.82 & 29.66 & 18.01 & 16.94 & 1.39 & 1.56 & 0.12 & 12.86 \\
\hline $\mathrm{ZnO}$ & - & - & - & - & - & - & - & - & 0.38 & 0.23 & - & - & - & - & - & - & - & 1.64 \\
\hline MnO & 5.41 & 0.24 & 0.03 & 0.01 & 0.01 & 0.03 & - & - & 0.09 & 0.02 & 0.33 & 0.30 & 0.00 & 0.00 & 0.00 & 0.01 & - & 0.12 \\
\hline MgO & 0.89 & 3.51 & 8.49 & 8.93 & 0.45 & 0.44 & - & - & 1.75 & 1.55 & 4.63 & 5.13 & 10.59 & 9.85 & 0.91 & 1.76 & - & 1.55 \\
\hline $\mathrm{CaO}$ & 6.49 & 2.03 & 0.14 & 0.03 & 0.03 & 0.10 & 6.25 & 2.27 & 0.00 & 0.01 & 5.17 & 5.47 & 0.04 & 0.10 & 0.04 & 0.02 & 14.31 & 0.01 \\
\hline $\mathrm{Na}_{2} \mathrm{O}$ & - & - & 0.18 & 0.21 & 1.99 & 1.75 & 8.02 & 10.44 & - & - & - & - & 0.23 & 0.25 & 0.60 & 0.47 & 3.19 & - \\
\hline $\mathrm{K}_{2} \mathrm{O}$ & - & - & 7.63 & 7.95 & 7.07 & 6.96 & 0.06 & 0.19 & 0.02 & 0.00 & - & - & 8.97 & 8.86 & 9.73 & 10.16 & 0.06 & 0.00 \\
\hline Tot. & 100.72 & 101.17 & 94.63 & 95.42 & 95.04 & 94.44 & 99.71 & 98.54 & 96.85 & 97.30 & 101.57 & 101.90 & 96.40 & 94.31 & 93.29 & 94.71 & 101.15 & 99.48 \\
\hline O basis & 12 & 12 & 11 & 11 & 11 & 11 & 32 & 32 & 46 & 46 & 12 & 12 & 11 & 11 & 11 & 11 & 32 & 46 \\
\hline $\mathrm{Si}$ & 3.03 & 3.00 & 2.77 & 2.74 & 3.08 & 3.13 & 10.91 & 11.33 & 7.87 & 7.88 & 2.95 & 2.96 & 2.73 & 2.68 & 3.03 & 3.20 & 9.10 & 7.58 \\
\hline $\mathrm{Al}^{\mathrm{IV}}$ & 0.00 & 0.00 & 1.23 & 1.26 & 0.92 & 0.87 & 5.00 & 4.71 & 0.13 & 0.12 & 0.05 & 0.04 & 0.27 & 0.32 & 0.97 & 0.80 & 6.98 & 0.42 \\
\hline $\mathrm{Al}^{\mathrm{VI}}$ & 1.92 & 1.95 & 0.39 & 0.39 & 1.93 & 1.92 & - & - & 17.13 & 17.23 & 2.00 & 2.01 & 1.48 & 1.47 & 1.83 & 1.73 & - & 17.22 \\
\hline $\mathrm{Ti}$ & 0.00 & 0.00 & 0.06 & 0.09 & 0.02 & 0.02 & - & - & 0.15 & 0.12 & 0.00 & 0.00 & 0.13 & 0.14 & 0.04 & 0.02 & - & 0.15 \\
\hline $\mathrm{Cr}$ & 0.00 & 0.00 & 0.00 & 0.00 & 0.00 & 0.01 & - & - & 0.00 & 0.00 & 0.01 & 0.01 & 0.01 & 0.01 & 0.02 & 0.02 & - & 0.13 \\
\hline $\mathrm{Fe}^{3+}$ & 0.02 & 0.05 & - & - & - & - & 0.06 & 0.01 & - & - & 0.03 & 0.01 & - & - & - & - & 0.02 & - \\
\hline $\mathrm{Fe}^{2+}$ & 2.00 & 2.40 & 1.53 & 1.35 & 0.05 & 0.04 & - & - & 3.24 & 3.29 & 1.97 & 1.91 & 1.08 & 1.07 & 0.08 & 0.09 & - & 2.95 \\
\hline $\mathrm{Zn}$ & - & - & - & - & - & - & - & - & 0.08 & 0.05 & - & - & - & - & - & - & - & 0.33 \\
\hline $\mathrm{Mn}$ & 0.37 & 0.02 & 0.00 & 0.00 & 0.00 & 0.00 & - & - & 0.02 & 0.00 & 0.02 & 0.02 & 0.00 & 0.00 & 0.00 & 0.00 & - & 0.03 \\
\hline $\mathrm{Mg}$ & 0.11 & 0.42 & 0.98 & 1.11 & 0.04 & 0.04 & - & - & 0.73 & 0.64 & 0.54 & 0.59 & 1.15 & 1.11 & 0.09 & 0.18 & - & 0.63 \\
\hline $\mathrm{Ca}$ & 0.56 & 0.17 & 0.01 & 0.00 & 0.00 & 0.01 & 1.19 & 0.44 & 0.00 & 0.00 & 0.43 & 0.45 & 0.00 & 0.00 & 0.00 & 0.00 & 2.74 & 0.00 \\
\hline $\mathrm{Na}$ & - & - & 0.03 & 0.03 & 0.25 & 0.22 & 2.77 & 3.62 & - & - & - & - & 0.02 & 0.04 & 0.08 & 0.06 & 1.11 & - \\
\hline K & - & - & 0.75 & 0.77 & 0.59 & 0.58 & 0.01 & 0.04 & 0.00 & 0.00 & - & - & 0.87 & 0.86 & 0.84 & 0.87 & 0.01 & 0.00 \\
\hline Tot. & 8.00 & 8.00 & 7.75 & 7.75 & 6.89 & 6.85 & 19.94 & 20.15 & 29.35 & 29.33 & 8.00 & 8.00 & 7.73 & 7.72 & 6.98 & 6.97 & 19.96 & 29.42 \\
\hline
\end{tabular}


Table 3

Representative Electron Microprobe analyses (EMPA) of monazite grains (normalised to 40 ) in the selected samples for geochronology $(\mathrm{c}=$ cores, $\mathrm{m}=\mathrm{mantles,} \mathrm{r}=\mathrm{rims}$ ).

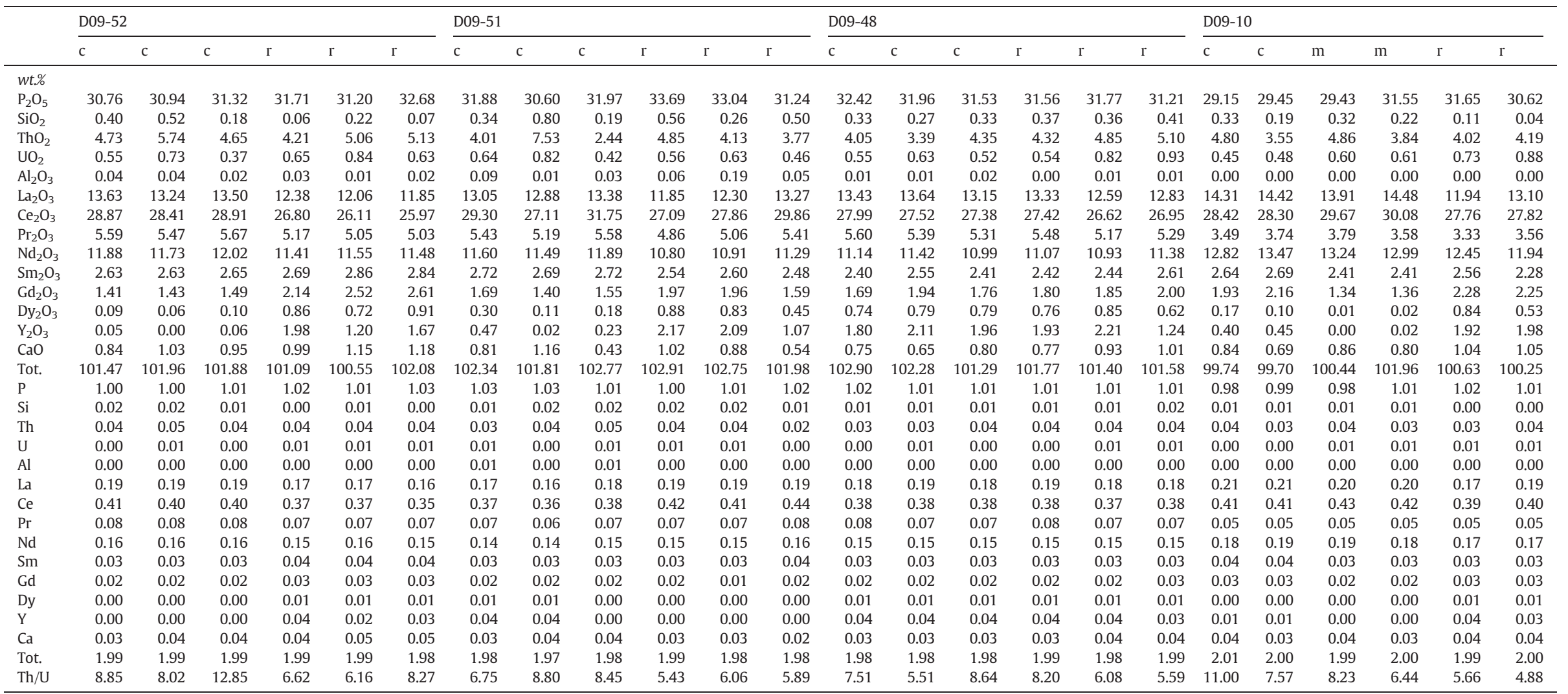


suggested by the occurrence of stable Aln well above the St-in isograd where Mnz should be the main LREE-bearing phase (Rubatto et al., 2001; Spear, 2010).

Biotite within garnet in sample D09-10 has lower XMg of $~ 0.40$ and Ti of $\sim 0.10$ a.p.f.u. with respect to matrix biotite (XMg: $0.45-0.50$; Ti: $0.15-0.18$ a.p.f.u.). This difference is not so marked in sample D09-11, where XMg and Ti a.p.f.u. slightly increase from 0.51 and 0.13-0.14 a.p.f.u to 0.51-0.53 and 0.14-0.16 a.p.f.u for biotite within Grt and biotite along foliation planes, respectively. Muscovite of sample D09-10 has the higher paragonite content of the studied samples $\left(\mathrm{Na}_{2} \mathrm{O}>1.5 \mathrm{wt} . \%\right)$ in accordance with the values expected for the muscovites crystallised in the staurolite zones (Cipriani et al., 1971). Muscovite in Grt is characterised by a lower $\mathrm{Si}^{4+}$ content (3.08-3.10) with respect to muscovite along foliation $\left(\mathrm{Si}^{4+}\right.$ of $\left.3.13-3.16\right)$. This trend is also present in muscovite of D09-11, where $\mathrm{Si}^{4+}$ varies from 3.03 to 3.06 of included grains to $3.18-3.20$ of matrix muscovite.

\subsection{Geothermometry, geobarometry, P-T-t paths}

In order to assess $\mathrm{P}-\mathrm{T}$ conditions from the hanging-wall and footwall rocks of shear zone we applied an internally consistent set of geothermobarometers on the selected samples (Fig. 4, Table 1).

$\mathrm{Wu}$ and Cheng (2006) made an extensive comparison of Grt-Bt (GARB) and Grt-Als-Qtz-Pl (GASP) geothermobarometer calibrations present in literature (at least 32 for GARB calibrations) in order to test the validity of the different calibrations in reproducing experimental data and the reliability for their extrapolation to natural samples. Following their results, we applied the GARB calibration of Holdaway (2000) in combination, where Als was present (samples D09-52, D09-10, D09-11), with GASP barometer of Holdaway (2001) and with garnet-biotite-plagioclase-quartz (GBPQ) and garnet-muscoviteplagioclase-quartz equilibria (GMPQ), respectively of $\mathrm{Wu}$ et al. (2004) and $\mathrm{Wu}$ and Zhao (2006). These last two barometers are very useful especially where no Als are present in the sample (i.e. D09-51). All these barometers are internally consistent with GARB and GASP calibrations of Holdaway $(2000,2001)$ and reproduce similar pressure estimates of the GASP (Wu and Zhao, 2006; Wu et al., 2004) (see Appendix 1 for more details on the $\mathrm{P}-\mathrm{T}$ estimation procedure).

\subsubsection{Results and interpretation}

$\mathrm{P}-\mathrm{T}$ results are reported in Table 4 and plotted on a KFMASH petrogenetic grid (Fig. 9) drawn with GIBBS software of Spear and Menard (1989), using the thermodynamic data file SPaC(1-2001). The retrograde path on the petrogenetic grid, for MSZ samples is constrained by the presence of sillimanite and the absence of K-feldspar and staurolite in the assemblage, while in the footwall rocks the retrograde path is constrained by the stability of kyanite \pm staurolite and the absence of chloritoid during the retrograde path.

A strong consistency between geothermobarometers is evident (Table 4), except for the GASP pressure estimates of sample D09-52. Taking into account their coherence with petrogenetic grid a good degree of equilibration of the samples (e.g. Spear, 1993) can be highlighted strengthening the meaning and the differences in the P-T estimates.

Table 4

$\mathrm{P}-\mathrm{T}$ results of the geothermobarometric investigation.

\begin{tabular}{lllll}
\hline Sample & $\mathrm{T}\left({ }^{\circ} \mathrm{C}\right)$ GARB & $\mathrm{P}(\mathrm{GPa})$ GASP & $\mathrm{P}(\mathrm{GPa}) \mathrm{GBPQ}$ & $\mathrm{P}(\mathrm{GPa}) \mathrm{GMPQ}$ \\
\hline $\mathrm{D} 09-10$ & 666 & 1.15 & 1.01 & 1.04 \\
$\mathrm{D} 09-11$ & 699 & 0.92 & 0.92 & 0.95 \\
D09-51 & 686 & - & 0.76 & 0.73 \\
D09-52 & 698 & 0.82 & 0.70 & 0.70 \\
\hline
\end{tabular}

Estimated errors according to authors: $\pm 25{ }^{\circ} \mathrm{C}$ (GARB), $\pm 0.08 \mathrm{GPa}$ (GASP), $\pm 0.12 \mathrm{GPa}$ (GBPQ), and $\pm 0.15 \mathrm{GPa}$ (GMPQ).
One explanation for the slightly higher P value (i.e. $0.82 \mathrm{GPa}$ ) obtained with GASP in the sample D09-52 could be found if we consider that XGrs of garnet composition used for P-T estimates is below 0.05 (in particular 0.047 , the lowest of the studied samples), a critical value for GASP barometer, since large discrepancy could be present when the grossular component is highly diluted in garnet, as pointed out by Todd (1998). It is worth to note that P median values are the same for both the study samples from shear zone hanging-wall $(0.74 \mathrm{GPa})$ and they are significantly lower than P values detected for footwall samples (1.0-0.9 GPa).

Application of internally consistent geothermobarometers clearly reveals a break of pressure array in correspondence of the MSZ. In particular MSZ juxtaposes lower pressure rocks ( 0.74 GPa) above higher pressure $(\sim 1.0-0.9 \mathrm{GPa})$ rocks with a gap in pressure of $\sim 0.2 \mathrm{GPa}$.

\section{U-Pb geochronology}

It is well established that monazite, (LREE, Th) $\mathrm{PO}_{4}$, is able to record deformation events (e.g. Williams and Jercinovic, 2002) and metamorphic reactions (e.g. Spear, 2010; Spear and Pyle, 2002, 2010 and reference therein) due to the ability of this mineral to undergo dissolution-(re-) precipitation at different P-T conditions (e.g. Dumond et al., 2008). Monazite results are also a good geochronometer (e.g. Parrish, 1990) and the in situ geochronological techniques offer the possibility of linking absolute ages to particular chemical domains related to metamorphic reactions and/or deformation events (e.g. Foster and Parrish, 2003; Foster et al., 2000; Gibson et al., 2004). For these reasons, monazites from samples of different structural positions were investigated, in order to compare the P-T-D-t evolution of rocks from footwall and hanging-wall of the MSZ.

\subsection{Monazite textural setting, chemistry and zoning}

Monazite grains from all study samples (D09-52, D09-51,D09-48, D09-10) have been characterised for textural position, shape, size, inclusions and internal features by both optical and electron microscope (SEM).

In hanging-wall samples (D09-52, D09-51, D09-48) monazite is present as small crystals that rarely exceed $100 \mu \mathrm{m}$ in length. Monazite grains lie only along the mylonitic foliation and locally they coexist, or are in contact, with xenotime. Monazite and xenotime are absent within garnet where only tiny allanite grains were found. Monazite crystals contain different inclusions as function of the textural position: monazite grains within Q-Domain (quartz rich domain, Shelley, 1993) contain quartz inclusions whereas Wm, Bt and Grt have been observed within monazite grains from the P-Domains (phyllosilicate-rich domain, Shelley, 1993). Rare Zrn inclusions occur. SEM-BSE images do not allow the recognition of a clear chemical variation, however a chemical variation of some elements, such as yttrium, cannot be excluded (e.g. Gibson et al., 2004).

Electron microprobe analysis (EMPA) observations, instead, revealed a more complex zoning pattern (Fig. 10a), with the clear identification of two distinct chemical domains within monazite grains from samples D09-52 and D09-51. These two domains are mainly characterised by a different $\mathrm{Y}_{2} \mathrm{O}_{3}$ contents: $>1.0$ and $<0.5$ wt.\%. The two groups of Mnz, in the hanging-wall samples, are defined as: (i) Mnz $1_{(\mathrm{hw})}$ with low $\mathrm{Y}+\mathrm{HREE}$ content $(<0.04$ a.p.f.u.) forming the interior of the crystals and (ii) $M n z 2_{(h w)}$ with high Y + HREE (>0.06 a.p.f.u.) forming discontinuous rims and mottled zone on the previous one. This trend is present only in two samples (i.e. D09-51, D09-52), while it is not so evident in the third sample (D09-48) (Fig. 10a). It is also important to note the anticorrelation between HREE and LREE, suggesting mainly a substitution between REEs for incorporation of HREE in monazite structure.

In the footwall sample (D09-10) monazite is present as very tiny inclusions $(<10 \mu \mathrm{m})$ coexisting with xenotime as Grt inclusions and as large crystals (up to $400 \mu \mathrm{m}$ ) in the matrix. In one case, Mnz was also 


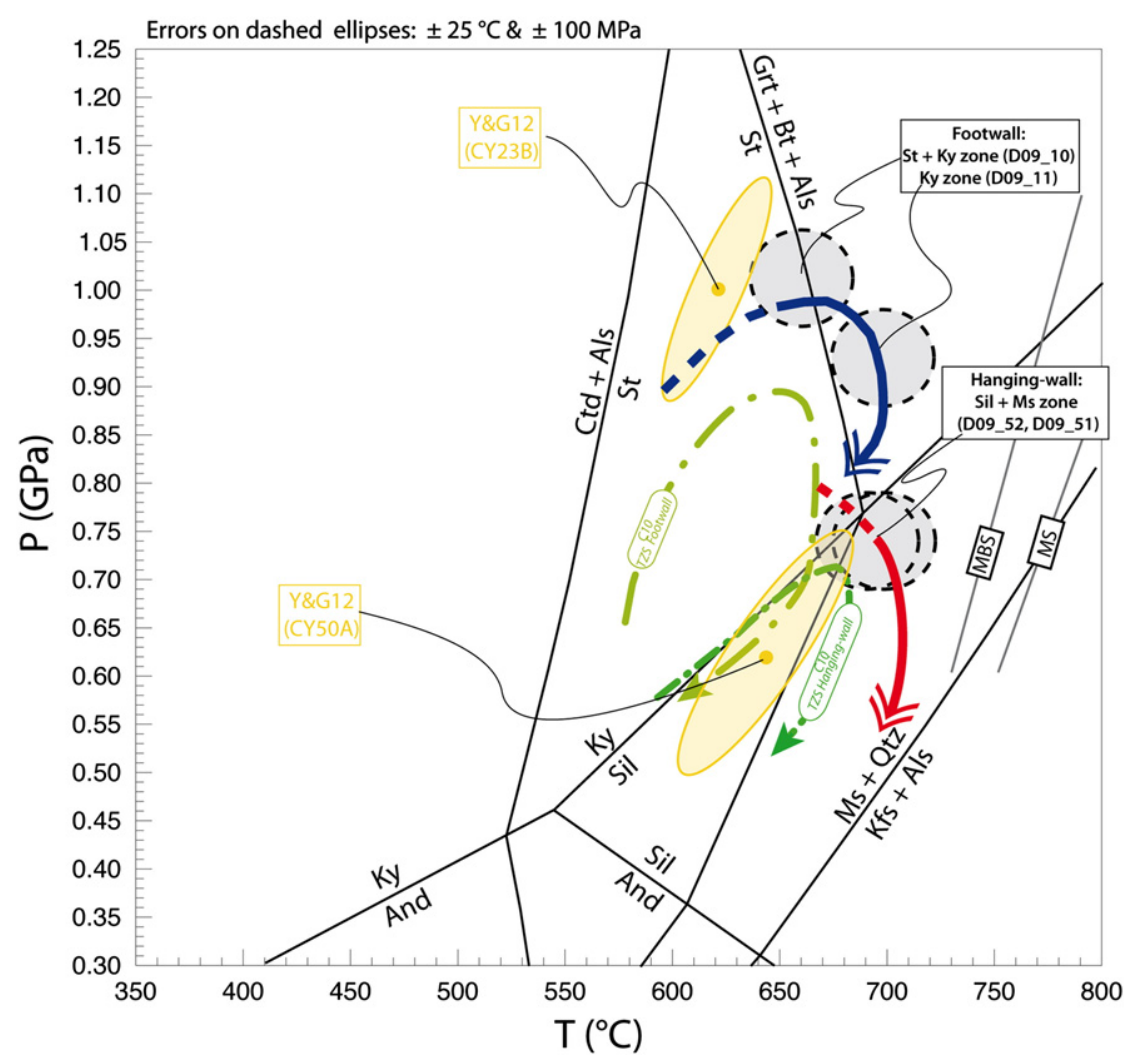

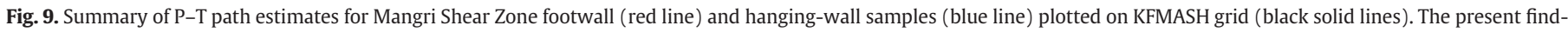

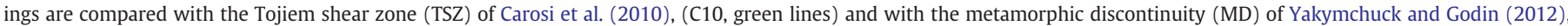

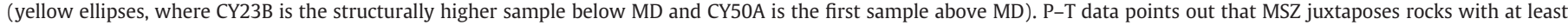

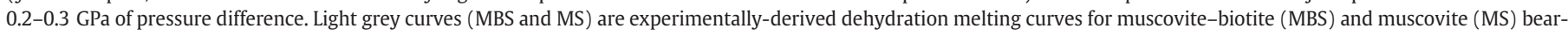
ing schists from GHS (Patiño-Douce and Harris, 1998).

detected along internal foliation in St porphyroblasts. Other phosphate minerals present in the matrix are Ap and Xtm. The latter is always present with texturally late biotite as a garnet breakdown product. Chemically, monazite in Grt is characterised by an Y + HREE variable composition (Fig. 10a) from very rich composition (between 0.06 and 0.09 a.p.f.u.) to medium composition (0.04-0.05). Matrix monazite can be subdivided into three main groups (Fig. 10a): (i) Mnz $1_{(\mathrm{fw})}$ occurring as cores with medium Y + HREE content not so far from the composition of same Mnz inside the garnet (0.035-0.04 a.p.f.u.), (ii) Mnz $2_{(\mathrm{fw})}$ with low Y + HREE (below 0.025 a.p.f.u.) forming rims around the $\operatorname{Mnz} 1_{(\mathrm{fw})}$ and (iii) $\mathrm{Mnz}_{(\mathrm{fw})}$ forming a discontinuous tiny $\operatorname{rim}(\leq 10-15 \mu \mathrm{m})$ on the previous generation of $\mathrm{Mnz} 2_{(\mathrm{fw})}$ with a composition enriched in $\mathrm{Y}$ and HREE.

All monazite analyses, according to Linthout (2007), plot quite near the monazite end-member apex in the triangular plot monazitehuttonite-cheralite (Fig. 10b). The entrance of Th and $U$ in the crystal structure of monazite is well explainable with a combination of cheralite plus huttonite vector substitution (Fig. 10b).

Anomalous values of $\mathrm{Y}, \mathrm{Th}, \mathrm{U}$ and $\mathrm{Th} / \mathrm{U}$ ratio (in combination with chronological/textural information) can help to detect late stage (younger) monazite related to late fluid infiltration (e.g. Corrie and Kohn, 2011; Kohn et al., 2005). Since we do not found these evidences, late stage fluids infiltration could be excluded.

\subsection{In situ monazite $U-(T h)-P b$ LA-ICP-MS geochronology}

Monazite grains were analysed in situ by laser-ablation, inductively coupled, plasma mass spectrometry (LA-ICP-MS) on 30- $\mu$ m-thick sections at the CNR-Istituto di Geoscienze e Georisorse U.O. Pavia (Italy) using an Ar-F 193-nm excimer laser (GeolLas 102 from Micro-Las) coupled with a magnetic sector ICP-MS (Element I from ThermoFinnigan). The full description of analytical procedure is reported in Paquette and Tiepolo (2007) and Tiepolo (2003). Single analyses were performed by one-minute acquisition of the background signal followed by the acquisition of the ablation signal of masses of ${ }^{202} \mathrm{Hg}$, ${ }^{204}(\mathrm{Hg}+\mathrm{Pb}),{ }^{206} \mathrm{~Pb},{ }^{207} \mathrm{~Pb},{ }^{208} \mathrm{~Pb},{ }^{232} \mathrm{Th}$, and ${ }^{238} \mathrm{U}$, for at least $30 \mathrm{~s}$. ${ }^{202} \mathrm{Hg}$ is acquired in order to correct the isobaric interference of ${ }^{204} \mathrm{Hg}$ on ${ }^{204} \mathrm{~Pb}$ and to evaluate the presence of common lead in the sample. The ${ }^{235} \mathrm{U}$ is calculated from ${ }^{238} \mathrm{U}$ on the basis of constant natural ratio ${ }^{238} \mathrm{U} /{ }^{235} \mathrm{U}=137.88$. Analytical conditions were $12 \mathrm{~J} \mathrm{~cm}^{-2}$ of energy density, $3 \mathrm{~Hz}$ of repetition rate and $10 \mu \mathrm{m}$ diameter of spot size. Time resolved signal were carefully inspected to verify the presence of perturbations related to inclusions, fractures or mixing of different age domains. Laser-induced elemental fractionation and mass bias were corrected using matrix-matched external monazite standard (Moacir monazite: Cruz et al., 1996; Seydoux-Guillaume et al., 2002a,b) considering the values, re-calibrated for isotopic disequilibrium, reported by

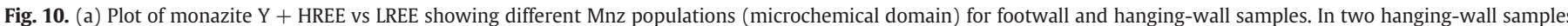

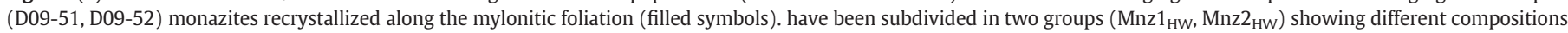

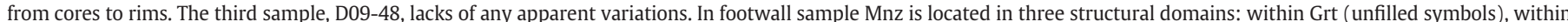

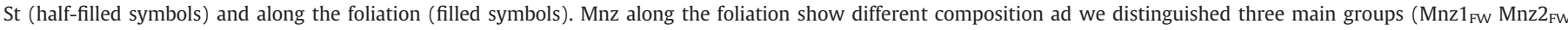

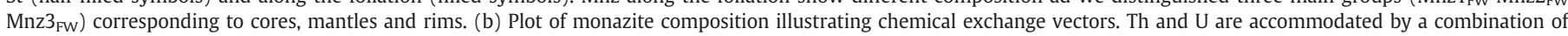
cheralite + huttonite substitutions as suggested by the strong linear correlation. 

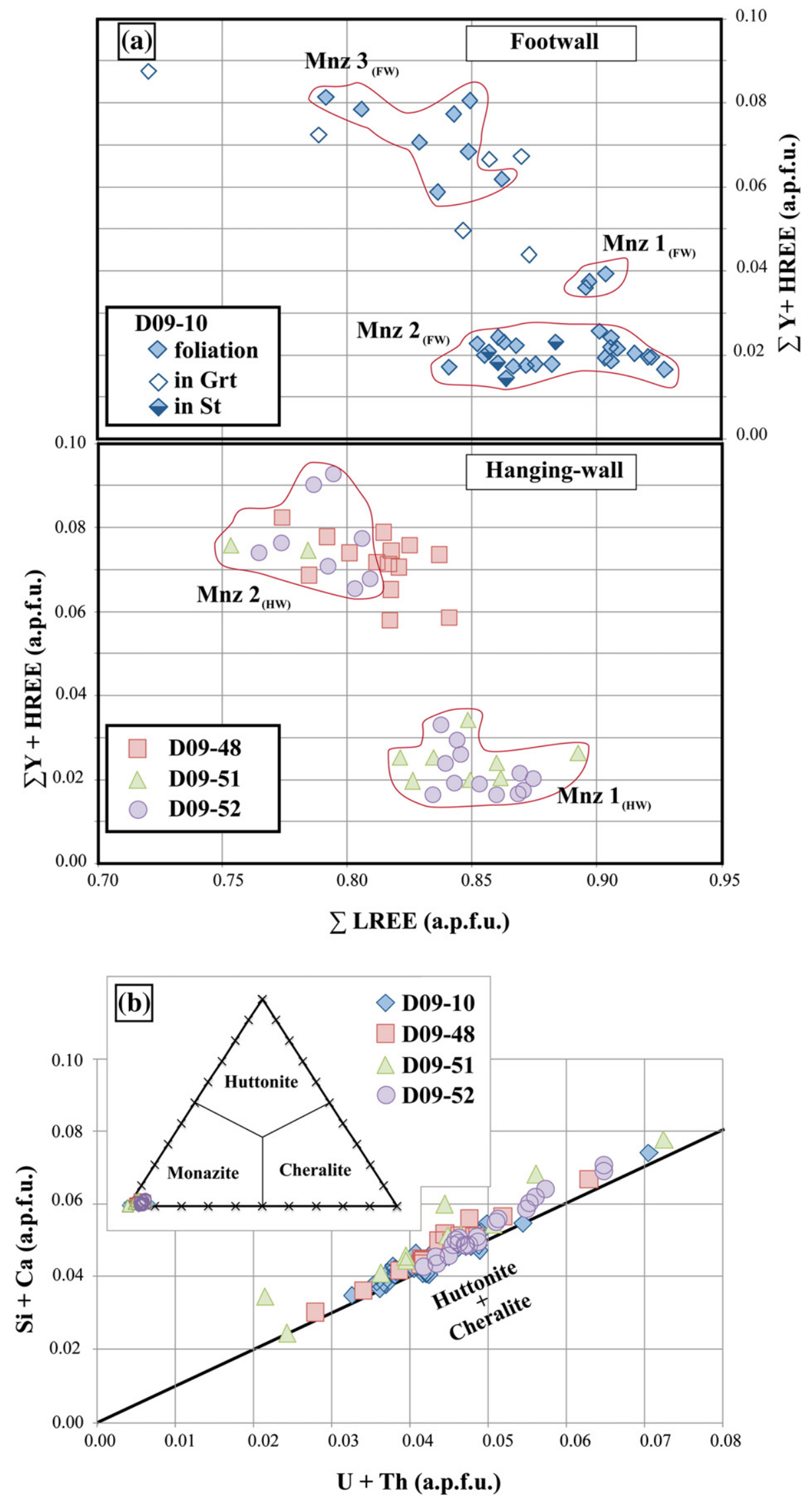
Table 5a

Mnz features, isotopic ratios and ages for hanging-wall sample D09-52 ( $1=$ length, $w=$ width $)$.

\begin{tabular}{|c|c|c|c|c|c|c|c|c|c|c|c|c|c|c|}
\hline \multirow[t]{2}{*}{ Mnz grain } & \multirow[t]{2}{*}{ Grain position } & \multirow{2}{*}{$\frac{\text { Area }}{\left(\mu \mathrm{m}^{2}\right)}$} & \multirow{2}{*}{$\frac{\mathrm{l} * \mathrm{w}}{(\mu \mathrm{m})}$} & \multirow[t]{2}{*}{ Spot position } & \multicolumn{6}{|l|}{ Isotopic ratio } & \multicolumn{4}{|l|}{ Ages } \\
\hline & & & & & ${ }^{207} \mathrm{~Pb} /{ }^{206} \mathrm{~Pb}$ & $1 \sigma \%$ & ${ }^{207} \mathrm{~Pb} /{ }^{235} \mathrm{U}$ & $1 \sigma \%$ & ${ }^{206} \mathrm{~Pb} /{ }^{238} \mathrm{U}$ & $1 \sigma \%$ & ${ }^{206} \mathrm{~Pb} /{ }^{238} \mathrm{U}$ & $2 \sigma a b s$ & ${ }^{207} \mathrm{~Pb} /{ }^{235} \mathrm{U}$ & $2 \sigma$ abs \\
\hline 137 & P domain & 16112 & $187 * 110$ & Rim & 0.10499 & $0.51 \%$ & 0.05213 & $0.27 \%$ & 0.00360 & $0.01 \%$ & 23 & 0.78 & 52 & 3.34 \\
\hline 137 & $"$ & $"$ & $"$ & Core & 0.13603 & $0.61 \%$ & 0.06257 & $0.31 \%$ & 0.00333 & $0.01 \%$ & 21 & 0.72 & 62 & 3.40 \\
\hline 137 & $"$ & $"$ & $"$ & Rim & 0.12481 & $0.59 \%$ & 0.05004 & $0.26 \%$ & 0.00290 & $0.01 \%$ & 19 & 0.66 & 50 & 3.10 \\
\hline 200 & P domain & $"$ & $"$ & Core & 0.10699 & $0.53 \%$ & 0.03899 & $0.21 \%$ & 0.00264 & $0.01 \%$ & 17 & 0.60 & 39 & 2.66 \\
\hline 133 & P domain & 3982 & $93 * 54$ & Rim & 0.14993 & $0.66 \%$ & 0.07341 & $0.36 \%$ & 0.00355 & $0.01 \%$ & 23 & 0.76 & 72 & 3.68 \\
\hline 133 & $"$ & $"$ & $"$ & Core & 0.11885 & $0.56 \%$ & 0.05399 & $0.28 \%$ & 0.00329 & $0.01 \%$ & 21 & 0.72 & 53 & 3.26 \\
\hline 131 & P domain & 4523 & $98 * 59$ & Rim & 0.11320 & $0.55 \%$ & 0.04522 & $0.24 \%$ & 0.00289 & $0.01 \%$ & 19 & 0.64 & 45 & 2.94 \\
\hline 131 & $"$ & $"$ & $"$ & Core & 0.11036 & $0.52 \%$ & 0.04930 & $0.25 \%$ & 0.00324 & $0.01 \%$ & 21 & 0.70 & 49 & 3.06 \\
\hline 134 & P domain & 2723 & $76 * 46$ & Rim & 0.09356 & $0.46 \%$ & 0.03376 & $0.18 \%$ & 0.00261 & $0.01 \%$ & 17 & 0.56 & 34 & 2.32 \\
\hline 134 & $"$ & $"$ & $"$ & Rim & 0.12372 & $0.64 \%$ & 0.04483 & $0.25 \%$ & 0.00262 & $0.01 \%$ & 17 & 0.62 & 45 & 3.28 \\
\hline 66 & P domain & 5992 & $116 * 66$ & Rim & 0.18975 & $0.78 \%$ & 0.09105 & $0.42 \%$ & 0.00348 & $0.01 \%$ & 22 & 0.72 & 89 & 3.78 \\
\hline 66 & $"$ & $"$ & $"$ & Rim & 0.16123 & $0.72 \%$ & 0.06930 & $0.34 \%$ & 0.00311 & $0.01 \%$ & 20 & 0.68 & 68 & 3.68 \\
\hline 139 & P domain & 6329 & $101 * 80$ & Rim & 0.15498 & $0.67 \%$ & 0.06897 & $0.33 \%$ & 0.00322 & $0.01 \%$ & 21 & 0.68 & 68 & 3.36 \\
\hline 139 & $"$ & $"$ & $"$ & Rim & 0.14799 & $0.60 \%$ & 0.07297 & $0.34 \%$ & 0.00357 & $0.01 \%$ & 23 & 0.70 & 72 & 3.04 \\
\hline 140 & P domain & 6896 & $132 * 67$ & Core & 0.12412 & $0.59 \%$ & 0.05256 & $0.27 \%$ & 0.00307 & $0.01 \%$ & 20 & 0.68 & 52 & 3.26 \\
\hline 140 & $"$ & $"$ & $"$ & Rim & 0.14357 & $0.70 \%$ & 0.06332 & $0.33 \%$ & 0.00320 & $0.01 \%$ & 21 & 0.74 & 62 & 4.10 \\
\hline 201 & $\mathrm{P}$ domain & 4282 & $89 * 61$ & Core & 0.10612 & $0.53 \%$ & 0.04317 & $0.23 \%$ & 0.00294 & $0.01 \%$ & 19 & 0.66 & 43 & 3.00 \\
\hline 201 & $"$ & $"$ & $"$ & Rim & 0.12923 & $0.66 \%$ & 0.04789 & $0.26 \%$ & 0.00268 & $0.01 \%$ & 17 & 0.62 & 48 & 3.38 \\
\hline 143 & P domain & 3556 & $102 * 44$ & Near rim & 0.11064 & $0.54 \%$ & 0.04560 & $0.24 \%$ & 0.00299 & $0.01 \%$ & 19 & 0.66 & 45 & 3.02 \\
\hline 143 & $"$ & $"$ & $"$ & Rim & 0.13800 & $1.08 \%$ & 0.05076 & $0.40 \%$ & 0.00268 & $0.01 \%$ & 17 & 0.96 & 50 & 6.54 \\
\hline 208 & P domain & 6953 & $134 * 66$ & Core & 0.11504 & $0.73 \%$ & 0.04473 & $0.29 \%$ & 0.00283 & $0.01 \%$ & 18 & 0.78 & 44 & 4.50 \\
\hline 208 & $"$ & $"$ & $"$ & Rim & 0.11366 & $0.70 \%$ & 0.04603 & $0.29 \%$ & 0.00295 & $0.01 \%$ & 19 & 0.78 & 46 & 4.44 \\
\hline 208bis & P domain & 3112 & $97 * 41$ & Core & 0.09980 & $0.67 \%$ & 0.03775 & $0.26 \%$ & 0.00275 & $0.01 \%$ & 18 & 0.78 & 38 & 4.12 \\
\hline 159 & P domain & 4404 & $97 * 58$ & Core & 0.16349 & $0.93 \%$ & 0.07088 & $0.42 \%$ & 0.00315 & $0.01 \%$ & 20 & 0.88 & 70 & 5.76 \\
\hline 25 & Tur & 3098 & $102 * 39$ & Near rim & 0.14644 & $0.67 \%$ & 0.06264 & $0.31 \%$ & 0.00310 & $0.01 \%$ & 20 & 0.68 & 62 & 3.56 \\
\hline 25 bis & Tur & 3382 & $87 * 49$ & Core & 0.08998 & $0.47 \%$ & 0.03874 & $0.22 \%$ & 0.00311 & $0.01 \%$ & 20 & 0.68 & 39 & 2.94 \\
\hline 148 & Q domain & 4344 & $86 * 64$ & Core & 0.18313 & $0.97 \%$ & 0.08793 & $0.49 \%$ & 0.00349 & $0.01 \%$ & 22 & 0.94 & 86 & 6.22 \\
\hline 156 & P domain & 9794 & $152 * 82$ & Rim & 0.11012 & $0.66 \%$ & 0.04007 & $0.25 \%$ & 0.00263 & $0.01 \%$ & 17 & 0.66 & 40 & 3.68 \\
\hline 156 & $"$ & $"$ & $"$ & Core & 0.16442 & $0.95 \%$ & 0.07324 & $0.43 \%$ & 0.00327 & $0.01 \%$ & 21 & 0.94 & 72 & 5.98 \\
\hline 156 & $"$ & $"$ & $"$ & Rim & 0.09799 & $0.60 \%$ & 0.03740 & $0.24 \%$ & 0.00277 & $0.01 \%$ & 18 & 0.72 & 37 & 3.60 \\
\hline 209 & $"$ & $"$ & $"$ & Core & 0.13397 & $0.70 \%$ & 0.05501 & $0.30 \%$ & 0.00297 & $0.01 \%$ & 19 & 0.72 & 54 & 4.00 \\
\hline 210 & P domain & 587 & $29 * 26$ & Core & 0.13918 & $0.71 \%$ & 0.05075 & $0.27 \%$ & 0.00264 & $0.01 \%$ & 17 & 0.64 & 50 & 3.48 \\
\hline 153 & $"$ & 2120 & $60 * 45$ & Core & 0.08289 & $0.52 \%$ & 0.03332 & $0.22 \%$ & 0.00292 & $0.01 \%$ & 19 & 0.74 & 33 & 3.34 \\
\hline 153 & $"$ & $"$ & $"$ & Rim & 0.11540 & $0.65 \%$ & 0.04703 & $0.28 \%$ & 0.00296 & $0.01 \%$ & 19 & 0.72 & 47 & 3.90 \\
\hline
\end{tabular}

Gasquet et al. (2010). External standard and unknowns were integrated over the same time intervals to ensure the efficient correction of fractionation effects. Data reduction was carried with the software package GLITTER ${ }^{\circledR}$ (van Achterbergh et al., 2001). In order to have a better estimate of uncertainty affecting the isotopic ratios, the individual uncertainties given by GLITTER $®$, were propagated relative to respective reproducibility of the standard following the procedure as reported in Horstwood et al. (2003). After this error propagation each analysis is retained accurate within quoted errors. Analytical details and results of unknown and standards are reported in Tables 5a, 5b, 5c and $5 d$ and Appendix 2, respectively. Data processing and graphic representation were made with Isoplot 3.0 software (Ludwig, 2000). Mixing of

Table 5b

Mnz features, isotopic ratios and ages for hanging-wall sample D09-51( $1=$ length, $\mathrm{w}=$ width $)$.

\begin{tabular}{|c|c|c|c|c|c|c|c|c|c|c|c|c|c|c|}
\hline \multirow[t]{2}{*}{ Mnz grain } & \multirow[t]{2}{*}{ Grain position } & \multirow{2}{*}{$\frac{\text { Area }}{\left(\mu \mathrm{m}^{2}\right)}$} & \multirow{2}{*}{$\frac{1 * \mathrm{w}}{(\mu \mathrm{m})}$} & \multirow[t]{2}{*}{ Spot position } & \multicolumn{6}{|l|}{ Isotopic ratio } & \multicolumn{4}{|l|}{ Ages } \\
\hline & & & & & ${ }^{207} \mathrm{~Pb} /{ }^{206} \mathrm{~Pb}$ & $1 \sigma \%$ & ${ }^{207} \mathrm{~Pb} /{ }^{235} \mathrm{U}$ & $1 \sigma \%$ & ${ }^{206} \mathrm{~Pb} /{ }^{238} \mathrm{U}$ & $1 \sigma \%$ & ${ }^{206} \mathrm{~Pb} /{ }^{238} \mathrm{U}$ & $2 \sigma \mathrm{abs}$ & ${ }^{207} \mathrm{~Pb} /{ }^{235} \mathrm{U}$ & $2 \sigma \mathrm{abs}$ \\
\hline 305bis & P domain & 4108 & $105 * 50$ & Core & 0.12275 & $0.45 \%$ & 0.05583 & $0.19 \%$ & 0.00330 & $0.01 \%$ & 21 & 0.78 & 55 & 3.34 \\
\hline 171 & $\mathrm{Q}$ domain & 2126 & $65 * 41$ & Core & 0.12812 & $0.29 \%$ & 0.06492 & $0.13 \%$ & 0.00368 & $0.01 \%$ & 24 & 0.70 & 64 & 1.96 \\
\hline 174 & Q domain & 174 & $38 * 26$ & Core & 0.10629 & $0.28 \%$ & 0.04563 & $0.11 \%$ & 0.00312 & $0.01 \%$ & 20 & 0.60 & 45 & 1.78 \\
\hline 190 & P domain & 1443 & $74 * 25$ & Core & 0.06970 & $0.18 \%$ & 0.02776 & $0.07 \%$ & 0.00289 & $0.00 \%$ & 19 & 0.54 & 28 & 1.10 \\
\hline 128 & P domain & 3794 & $116 * 42$ & Core & 0.18009 & $0.40 \%$ & 0.08841 & $0.17 \%$ & 0.00356 & $0.01 \%$ & 23 & 0.66 & 86 & 2.40 \\
\hline 126 & P domain & 2944 & $118 * 32$ & Core & 0.17866 & $0.40 \%$ & 0.09725 & $0.19 \%$ & 0.00395 & $0.01 \%$ & 25 & 0.74 & 94 & 2.66 \\
\hline 126 & $"$ & $"$ & $"$ & Core & 0.16105 & $0.36 \%$ & 0.08567 & $0.17 \%$ & 0.00386 & $0.01 \%$ & 25 & 0.72 & 84 & 2.42 \\
\hline 310 & P domain & 573 & $33 * 22$ & Core & 0.14194 & $0.47 \%$ & 0.06365 & $0.19 \%$ & 0.00325 & $0.01 \%$ & 21 & 0.74 & 63 & 3.32 \\
\hline 123 & P domain & 1102 & $47 * 32$ & Core & 0.13432 & $0.32 \%$ & 0.06302 & $0.13 \%$ & 0.00341 & $0.01 \%$ & 22 & 0.64 & 62 & 2.00 \\
\hline 113 & Q domain & 667 & $34 * 25$ & Core & 0.13464 & $0.53 \%$ & 0.05867 & $0.21 \%$ & 0.00318 & $0.01 \%$ & 21 & 0.80 & 58 & 3.82 \\
\hline 312 & Q domain & 1102 & $47 * 30$ & Core & 0.10425 & $0.25 \%$ & 0.04372 & $0.09 \%$ & 0.00304 & $0.00 \%$ & 20 & 0.56 & 44 & 1.40 \\
\hline $313 a$ & Q domain & 4560 & $109 * 53$ & Rim & 0.10153 & $0.24 \%$ & 0.04226 & $0.09 \%$ & 0.00302 & $0.00 \%$ & 19 & 0.56 & 42 & 1.40 \\
\hline $313 a$ & $"$ & $"$ & $"$ & Rim & 0.10756 & $0.25 \%$ & 0.04600 & $0.09 \%$ & 0.00310 & $0.00 \%$ & 20 & 0.56 & 46 & 1.40 \\
\hline 26 & Q domain & 22859 & $210 * 138$ & Rim & 0.09763 & $0.23 \%$ & 0.04318 & $0.09 \%$ & 0.00321 & $0.01 \%$ & 21 & 0.58 & 43 & 1.42 \\
\hline 26 & $"$ & $"$ & $"$ & Core & 0.09001 & $0.22 \%$ & 0.03933 & $0.09 \%$ & 0.00317 & $0.01 \%$ & 20 & 0.58 & 39 & 1.40 \\
\hline 26 & $"$ & $"$ & $"$ & Rim & 0.10104 & $0.26 \%$ & 0.04356 & $0.10 \%$ & 0.00313 & $0.01 \%$ & 20 & 0.58 & 43 & 1.62 \\
\hline 26 & $"$ & $"$ & $"$ & Core & 0.12300 & $0.30 \%$ & 0.05702 & $0.13 \%$ & 0.00336 & $0.01 \%$ & 22 & 0.62 & 56 & 1.92 \\
\hline 26 & $"$ & $"$ & $"$ & Rim & 0.12793 & $0.44 \%$ & 0.05647 & $0.18 \%$ & 0.00321 & $0.01 \%$ & 21 & 0.72 & 56 & 3.08 \\
\hline 86 & P domain & 3804 & $86 * 56$ & Rim & 0.15806 & $0.48 \%$ & 0.07620 & $0.21 \%$ & 0.00350 & $0.01 \%$ & 23 & 0.72 & 75 & 3.40 \\
\hline 86 & " & $"$ & $"$ & Rim & 0.15637 & $0.46 \%$ & 0.08130 & $0.22 \%$ & 0.00377 & $0.01 \%$ & 24 & 0.78 & 79 & 3.56 \\
\hline 86bis & P domain & 1177 & $52 * 29$ & Rim & 0.14214 & $0.37 \%$ & 0.06817 & $0.16 \%$ & 0.00348 & $0.01 \%$ & 22 & 0.66 & 67 & 2.44 \\
\hline 94bis & P domain & 1959 & $62 * 40$ & Rim & 0.16024 & $0.62 \%$ & 0.07811 & $0.28 \%$ & 0.00353 & $0.01 \%$ & 23 & 0.86 & 76 & 4.82 \\
\hline 74 & P domain & 1459 & $44 * 42$ & Near rim & 0.12826 & $0.34 \%$ & 0.06498 & $0.15 \%$ & 0.00368 & $0.01 \%$ & 24 & 0.70 & 64 & 2.46 \\
\hline
\end{tabular}


Table 5c

Mnz features, isotopic ratios and ages for hanging-wall sample D09-48 ( 1 = length, w = width).

\begin{tabular}{|c|c|c|c|c|c|c|c|c|c|c|c|c|c|c|}
\hline \multirow[t]{2}{*}{ Mnz grain } & \multirow[t]{2}{*}{ Grain position } & \multirow{2}{*}{$\frac{\text { Area }}{\left(\mu \mathrm{m}^{2}\right)}$} & \multirow{2}{*}{$\frac{\mathrm{l} * \mathrm{w}}{(\mu \mathrm{m})}$} & \multirow[t]{2}{*}{ Spot position } & \multicolumn{6}{|l|}{ Isotopic ratio } & \multicolumn{4}{|l|}{ Ages } \\
\hline & & & & & ${ }^{207} \mathrm{~Pb} /{ }^{206} \mathrm{~Pb}$ & $1 \sigma \%$ & ${ }^{207} \mathrm{~Pb} /{ }^{235} \mathrm{U}$ & $1 \sigma \%$ & ${ }^{206} \mathrm{~Pb} /{ }^{238} \mathrm{U}$ & $1 \sigma \%$ & ${ }^{206} \mathrm{~Pb} /{ }^{238} \mathrm{U}$ & $2 \sigma$ abs & ${ }^{207} \mathrm{~Pb} /{ }^{235} \mathrm{U}$ & $2 \sigma$ abs \\
\hline 16 & Q domain & 1824 & $53 * 44$ & Core & 0.09178 & $0.53 \%$ & 0.03712 & $0.01 \%$ & 0.00294 & $0.21 \%$ & 19 & 0.78 & 37 & 1.81 \\
\hline 35 & Q domain & 2452 & $90 * 35$ & Rim & 0.12511 & $0.52 \%$ & 0.04971 & $0.01 \%$ & 0.00288 & $0.20 \%$ & 19 & 0.70 & 49 & 1.52 \\
\hline 36 & $"$ & $"$ & $"$ & Core & 0.28959 & $1.12 \%$ & 0.16243 & $0.01 \%$ & 0.00409 & $0.59 \%$ & 26 & 1.10 & 153 & 3.80 \\
\hline 29 & P domain & 4877 & $100 * 62$ & Rim & 0.05250 & $0.24 \%$ & 0.01983 & $0.01 \%$ & 0.00274 & $0.09 \%$ & 18 & 0.60 & 20 & 0.74 \\
\hline 29 & $"$ & $"$ & $"$ & Rim & 0.07489 & $0.32 \%$ & 0.03027 & $0.01 \%$ & 0.00293 & $0.12 \%$ & 19 & 0.66 & 30 & 0.99 \\
\hline 50 & P domain & 4372 & $121 * 56$ & Rim & 0.06224 & $0.31 \%$ & 0.02297 & $0.01 \%$ & 0.00268 & $0.11 \%$ & 17 & 0.62 & 23 & 0.94 \\
\hline 50 & $"$ & $"$ & $"$ & Rim & 0.05287 & $0.26 \%$ & 0.01922 & $0.01 \%$ & 0.00264 & $0.09 \%$ & 17 & 0.60 & 19 & 0.80 \\
\hline 51 & Q domain & 4242 & $113 * 48$ & Rim & 0.06553 & $0.31 \%$ & 0.02516 & $0.01 \%$ & 0.00279 & $0.12 \%$ & 18 & 0.64 & 25 & 0.97 \\
\hline 51 & $"$ & $"$ & $"$ & Rim & 0.06489 & $0.35 \%$ & 0.02457 & $0.01 \%$ & 0.00275 & $0.13 \%$ & 18 & 0.66 & 25 & 1.11 \\
\hline 53 & P domain & 2128 & $89 * 30$ & Rim & 0.11791 & $0.63 \%$ & 0.04434 & $0.01 \%$ & 0.00273 & $0.23 \%$ & 18 & 0.78 & 44 & 1.94 \\
\hline 301 & P domain & 2195 & $79 * 36$ & Rim & 0.05179 & $0.29 \%$ & 0.01977 & $0.01 \%$ & 0.00277 & $0.11 \%$ & 18 & 0.66 & 20 & 0.98 \\
\hline 58 & P domain & 3528 & $90 * 50$ & Rim & 0.31722 & $0.98 \%$ & 0.17811 & $0.01 \%$ & 0.00407 & $0.52 \%$ & 26 & 0.84 & 166 & 2.53 \\
\hline 81 & P domain & 3320 & $109 * 39$ & Rim & 0.24628 & $0.75 \%$ & 0.11993 & $0.01 \%$ & 0.00353 & $0.35 \%$ & 23 & 0.72 & 115 & 1.79 \\
\hline 85 & P domain & 2120 & $83 * 54$ & Rim & 0.05858 & $0.30 \%$ & 0.02124 & $0.01 \%$ & 0.00263 & $0.11 \%$ & 17 & 0.62 & 21 & 0.92 \\
\hline 85 & $"$ & $"$ & $"$ & Near rim & 0.17703 & $0.62 \%$ & 0.08027 & $0.01 \%$ & 0.00329 & $0.27 \%$ & 21 & 0.74 & 78 & 1.75 \\
\hline 94 & Q domain & 1800 & $61 * 38$ & Near rim & 0.24049 & $0.83 \%$ & 0.13382 & $0.01 \%$ & 0.00403 & $0.43 \%$ & 26 & 0.92 & 128 & 2.60 \\
\hline 94 & $"$ & $"$ & $"$ & Near rim & 0.10279 & $0.39 \%$ & 0.03713 & $0.00 \%$ & 0.00262 & $0.14 \%$ & 17 & 0.58 & 37 & 1.01 \\
\hline
\end{tabular}

age/chemical domains due to small size of both monazites and their chemical domain could be common (e.g. Kellett et al., 2010; Streule et al., 2010), therefore, we carefully check with EMPA all the analysed area by laser ablation.

Due to the young age expected and to the presence of common lead, we regressed the ${ }^{207} \mathrm{~Pb} /{ }^{206} \mathrm{~Pb}$ and ${ }^{206} \mathrm{~Pb} /{ }^{238} \mathrm{U}$ ratios on an inverse isochron plot (Tera and Wasserburg, 1972; Fig. 11a-d), following Kohn and Vervoort (2008). This plot, coupled with chemical and microstructural data can help to deconvolve and constrain end member mixing of ages (e.g. Cottle et al., 2009; Streule et al., 2010).

Monazite grains show length varying from 60 to $120 \mu \mathrm{m}$ in samples D09-52 and D09-48, they vary from 30 to $120 \mu \mathrm{m}$ in sample D09_51 and are bigger in sample D09-10 varying from 100 to $490 \mu \mathrm{m}$. Sizes of each dated monazite grains are reported in Tables 5a, 5b, 5c and 5d.

\subsection{Results and interpretation}

Geochronological results for all dated samples are presented in Fig. 11. Isotopic ratio are reported in Tables 5a, 5b, 5c and 5d.

\subsubsection{Hanging-wall samples}

A total of 34 analyses have been performed on 23 monazite grains from D09-52 (Fig. 11a). Five analyses from 5 crystals define a Discordia line with a lower intercept at $23.8 \pm 1.9$ (green ellipses), whereas 9 analyses from 7 monazite grains define a Discordia line with a lower intercept at $17.6 \pm 1.2 \mathrm{Ma}$ (yellow ellipses). 20 analyses from 15 crystals fall between the two main alignments (unfilled ellipses).

A total of 23 analyses were made on 17 monazite grains from sample D09-51 (Fig. 11b). Also in this case U-Pb data define two Discordia lines with lower intercept ages at $21.2 \pm 0.3$ (5 analyses, 4 grains) and $18.0 \pm 0.6 \mathrm{Ma}$ ( 8 analyses, 7 grains), respectively (grey ellipses and yellow ellipses). Ten analyses from 7 crystals fall between the two main alignments (unfilled ellipses).

A total of 17 analyses on 14 monazite grains from sample D09-48 have been collected (Fig. 11c). Also in this sample the Tera-Wasserburg plot shows that $\mathrm{U}-\mathrm{Pb}$ monazite data define two Discordia lines with lower intercept ages at $25.3 \pm 3.9$ ( 3 analyses, 3 grains, green ellipses) and $17.6 \pm 0.4 \mathrm{Ma}$ (9 analyses, 7 grains, yellow ellipses), respectively, with 4 analyses falling between the two intercepts.

In both the paragneisses (D09-52 and D09-51) U-Pb data show a correlation with the chemical composition of the analysed domains. Isotopic ratios defining the oldest alignments correspond to the $\mathrm{Y}_{2} \mathrm{O}_{3}$-poor chemical domains, whereas the $\mathrm{U}-\mathrm{Pb}$ data defining the youngest alignments have been obtained from the relatively $\mathrm{Y}_{2} \mathrm{O}_{3}$-rich domains. Despite U-Pb data giving comparable intercept ages with respect to the previous samples, a clear correlation between $\mathrm{Y}_{2} \mathrm{O}_{3}$ content and isotopic composition has not been observed for sample D09-48. Here,

Table 5d

Mnz features, isotopic ratios and ages for footwall sample D09-10 ( $1=$ length, $\mathrm{w}=$ width).

\begin{tabular}{|c|c|c|c|c|c|c|c|c|c|c|c|c|c|c|}
\hline \multirow[t]{2}{*}{ Mnz grain } & \multirow[t]{2}{*}{ Grain position } & \multirow{2}{*}{$\frac{\text { Area }}{\left(\mu \mathrm{m}^{2}\right)}$} & \multirow{2}{*}{$\frac{\mathrm{l} * \mathrm{w}}{(\mu \mathrm{m})}$} & \multirow[t]{2}{*}{ Spot position } & \multicolumn{6}{|l|}{ Isotopic ratio } & \multicolumn{4}{|l|}{ Ages } \\
\hline & & & & & ${ }^{207} \mathrm{~Pb} /{ }^{206} \mathrm{~Pb}$ & $1 \sigma \%$ & ${ }^{207} \mathrm{~Pb} /{ }^{235} \mathrm{U}$ & $1 \sigma \%$ & ${ }^{206} \mathrm{~Pb} /{ }^{238} \mathrm{U}$ & $1 \sigma \%$ & ${ }^{206} \mathrm{~Pb} /{ }^{238} \mathrm{U}$ & $2 \sigma \mathrm{abs}$ & ${ }^{207} \mathrm{~Pb} /{ }^{235} \mathrm{U}$ & $2 \sigma$ abs \\
\hline Mnz 203 & P domain & 60097 & $341 * 224$ & Core & 0.14762 & $0.48 \%$ & 0.06662 & $0.21 \%$ & 0.00329 & $0.01 \%$ & 21 & 0.66 & 65 & 4.19 \\
\hline Mnz 203 & P domain & $"$ & $"$ & Near core & 0.18510 & $0.50 \%$ & 0.08383 & $0.22 \%$ & 0.00329 & $0.01 \%$ & 21 & 0.66 & 82 & 4.38 \\
\hline Mnz 5 & P domain & 12309 & $187 * 83$ & Core & 0.16001 & $0.45 \%$ & 0.06641 & $0.18 \%$ & 0.00301 & $0.00 \%$ & 19 & 0.54 & 65 & 3.62 \\
\hline Mnz 5 & P domain & $"$ & " & Rim & 0.15077 & $0.59 \%$ & 0.04914 & $0.19 \%$ & 0.00237 & $0.00 \%$ & 15 & 0.59 & 49 & 3.69 \\
\hline Mnz 202 & P domain & 24472 & $272 * 115$ & Core & 0.19754 & $0.47 \%$ & 0.09054 & $0.22 \%$ & 0.00333 & $0.00 \%$ & 21 & 0.57 & 88 & 4.23 \\
\hline Mnz 202 & P domain & $"$ & $"$ & Near core & 0.16661 & $0.39 \%$ & 0.07735 & $0.18 \%$ & 0.00337 & $0.00 \%$ & 22 & 0.57 & 76 & 3.55 \\
\hline Mnz 202 & P domain & $"$ & $"$ & Rim & 0.13716 & $0.40 \%$ & 0.04413 & $0.13 \%$ & 0.00234 & $0.00 \%$ & 15 & 0.49 & 44 & 2.49 \\
\hline Mnz9 & in St & 4908 & $84 * 73$ & Core & 0.16010 & $0.40 \%$ & 0.07058 & $0.18 \%$ & 0.00320 & $0.00 \%$ & 21 & 0.56 & 69 & 3.50 \\
\hline Mnz9 & in St & $"$ & $"$ & Near core & 0.17561 & $0.43 \%$ & 0.08126 & $0.20 \%$ & 0.00336 & $0.00 \%$ & 22 & 0.57 & 79 & 3.88 \\
\hline Mnz9 & in St & $"$ & $"$ & Rim & 0.16352 & $0.37 \%$ & 0.07337 & $0.17 \%$ & 0.00326 & $0.00 \%$ & 21 & 0.56 & 72 & 3.31 \\
\hline Mnz1_to & P domain & 62733 & $488 * 164$ & Near core & 0.14200 & $0.69 \%$ & 0.05926 & $0.24 \%$ & 0.00303 & $0.00 \%$ & 20 & 0.62 & 58 & 4.77 \\
\hline Mnz1_to & P domain & $"$ & $"$ & Near core & 0.12806 & $0.63 \%$ & 0.05086 & $0.21 \%$ & 0.00289 & $0.00 \%$ & 19 & 0.60 & 50 & 4.17 \\
\hline Mnz 2_to & P domain & 63888 & $397 * 204$ & Core & 0.17222 & $0.90 \%$ & 0.07715 & $0.34 \%$ & 0.00325 & $0.01 \%$ & 21 & 0.73 & 75 & 6.69 \\
\hline Mnz 2_to & P domain & $"$ & $"$ & Rim & 0.13778 & $0.71 \%$ & 0.03966 & $0.17 \%$ & 0.00209 & $0.00 \%$ & 13 & 0.42 & 39 & 3.47 \\
\hline Mnz 6_to & P domain & 41263 & $471 * 112$ & Rim & 0.12673 & $0.64 \%$ & 0.04285 & $0.18 \%$ & 0.00245 & $0.00 \%$ & 16 & 0.55 & 43 & 3.60 \\
\hline Mnz 5_to & P domain & 102071 & $385 * 337$ & Core & 0.16813 & $0.84 \%$ & 0.07788 & $0.32 \%$ & 0.00337 & $0.01 \%$ & 22 & 0.75 & 76 & 6.35 \\
\hline Mnz 5_to & P domain & $"$ & $"$ & Rim & 0.10092 & $0.50 \%$ & 0.02881 & $0.12 \%$ & 0.00207 & $0.00 \%$ & 13 & 0.42 & 29 & 2.40 \\
\hline Mnz 5_to & P domain & $"$ & $"$ & Near core & 0.16104 & $0.77 \%$ & 0.06778 & $0.27 \%$ & 0.00306 & $0.00 \%$ & 20 & 0.62 & 67 & 5.29 \\
\hline
\end{tabular}



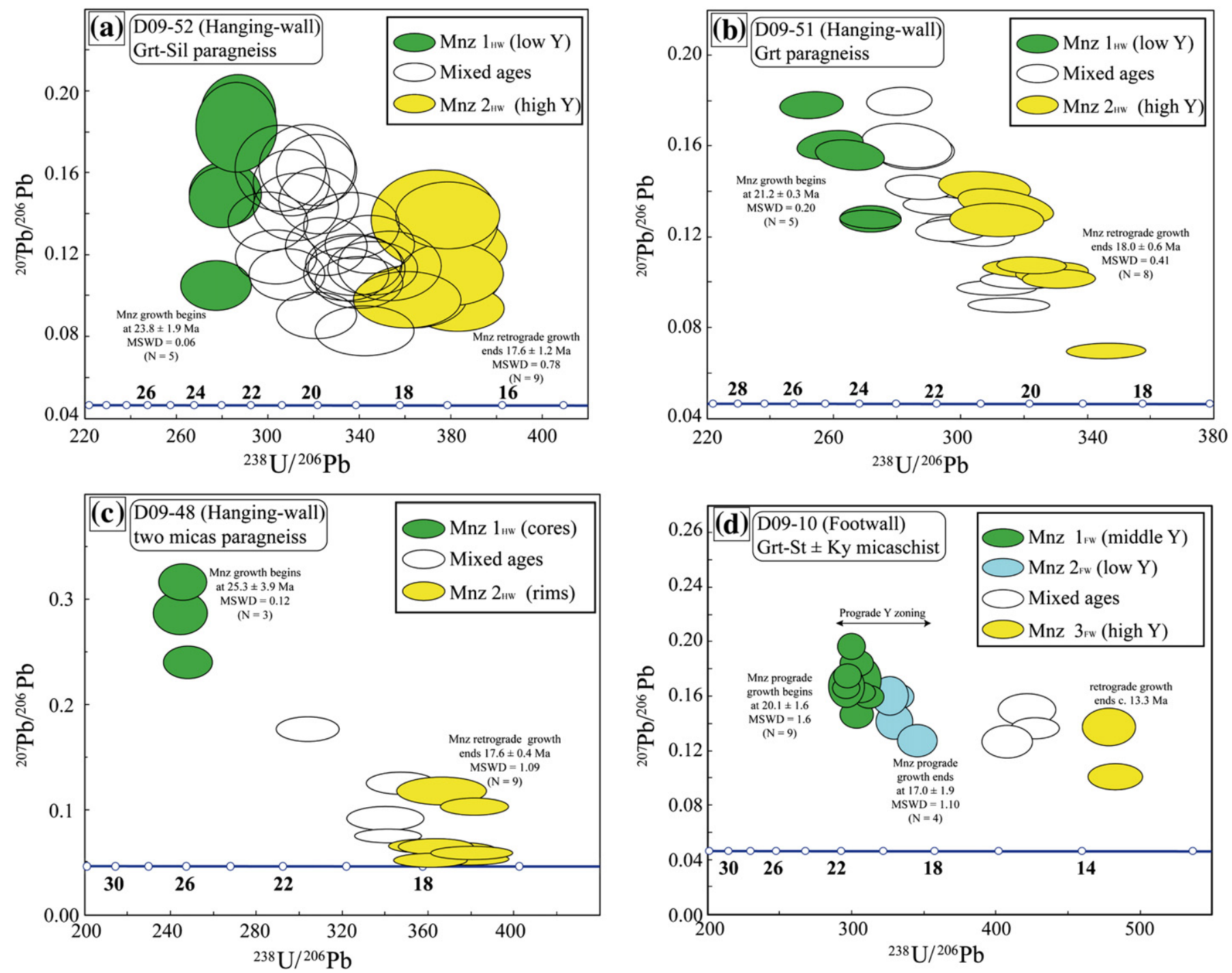

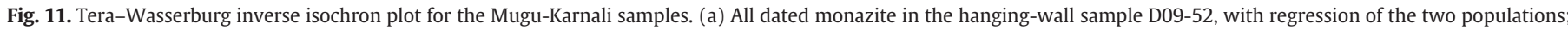

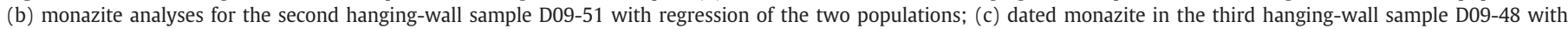
regression of the two populations; and (d) geochronological results for the footwall sample D09-10 with the interpretation of Mnz growth steps.

isotopic ratios seem to be related to the analytical spot position: the oldest intercept age is mainly defined by $\mathrm{U}-\mathrm{Pb}$ data from monazite cores.

Microstructurally equivalent monazite may contain different age populations which can be correlated with chemical and/or textural (e.g. core vs rim) domains (e.g. Cottle et al., 2009; Gibson et al., 2004; Langone et al., 2011; Martins et al., 2009). Monazite grains from two of the studied hanging-wall samples show a clear correlation between isotopic composition and $\mathrm{Y}_{2} \mathrm{O}_{3}$ content of the analysed domains suggesting two main episodes of monazite growth. The first generation of monazite ( $\left.\mathrm{Mnz} 1_{(\mathrm{hw})}\right)$ characterised by low $\mathrm{Y}_{2} \mathrm{O}_{3}$ (and HREE) content formed after the break-down of allanite under P-T conditions where garnet was still stable, at the metamorphic peak or at the beginning of the decompression/exhumation. The second episode of monazite growth ( $\left.M n z 2_{(\mathrm{hw})}\right)$ occurred coevally to garnet break-down during decompression and shearing along the MSZ. These two episodes of monazite growth have been recorded also by the Grt-free D09-48 sample. The lack of chemical (i.e. $\mathrm{Y}_{2} \mathrm{O}_{3}$ content, see Fig. 10a) vs age domains in this sample is probably due to the absence of garnet as major Y and HREE controlling phase. According to the structural and microstructural data (textural position; chemical analyses and isotopic composition of monazite), the shearing activity along the MSZ can be constrained between $\sim 25$ and $\sim 18 \mathrm{Ma}$. The difference between the oldest lower intercept ages of the D09-52 and D09-51 samples could be related to different $\mathrm{CaO}$ and $\mathrm{Al}_{2} \mathrm{O}_{3}$ contents of bulk rock compositions. According to Janots et al. (2008) and Spear (2010), the temperature of the allanite to monazite transition is strongly dependent on the bulk rock $\mathrm{CaO}$ and $\mathrm{Al}_{2} \mathrm{O}_{3}$ contents. This chemical control exerted by the bulk rock composition on the monazite (re-)crystallisation may also explain the systematic difference of monazite sizes observed between the two samples. The D09-52 sample is characterised by larger monazite grains, yielding the older lower intercept age, with respect to the D09-51 sample.

\subsubsection{Footwall sample}

A total of 18 analyses have been performed on 9 monazite grains from D09-10 (Fig. 11d). Nine analyses from 5 crystals cores define a Discordia line with a lower intercept at $20.1 \pm 1.6$ (green ellipses in Fig. 11d), whereas 4 analyses from 3 monazite grains define a Discordia line with a lower intercept at $17.0 \pm 1.9 \mathrm{Ma}$ (light blue ellipses in Fig. 11d). 3 analyses from 3 crystals fall between the two main alignments (unfilled ellipses in Fig. 11d). 2 youngest ages (yellow ellipses in Fig. 11d) at 13.3 Ma from 2 crystals rims also occur.

Monazite grains show a clear correlation between isotopic composition and $\mathrm{Y}_{2} \mathrm{O}_{3}$ content of the analysed chemical domains suggesting two 
main episodes of monazite growth. The first one ( $\left.\mathrm{Mnz} 1_{(\mathrm{fw})}-\mathrm{Mnz} 2_{(\mathrm{fw})}\right)$, between 20 and $17 \mathrm{Ma}$, is interpreted as a prograde (two steps) growth where the internal monazite domains coexist with Grt and Xtm (as Y buffer) whereas the mantle domains coexist only with Grt as Xtm was totally consumed (Rayleigh fractionation model, see for example Pyle and Spear, 1999; Foster and Parrish, 2003; Kohn et al., 2005). The second main episode of $M n z$ growth $\left(\mathrm{Mnz}_{(\mathrm{fw})}\right)$ at 13.3 Ma, is associated with Grt breakdown along the retrograde (decompression) path where Mnz (and possibly Xtm) was growing at expense of Grt (e.g. Foster and Parrish, 2003).

\section{Discussion and interpretation}

Detailed meso- and microstructural analyses led to the recognition of a thick ( $4 \mathrm{~km}$ ) shear zone (Mangri Shear Zone) in the core of the GHS. The shear zone, moderately dipping to the NE, shows a top-to-the-SW sense of shear. Its geometry and kinematics are coherent with contractional tectonics.

The age of the MSZ has been constrained between $\sim 25$ and $\sim 18 \mathrm{Ma}$ by $\mathrm{U}-\mathrm{Pb}$ on monazites along the mylonitic foliation.

$\mathrm{P}$ and $\mathrm{T}$ data by conventional geothermometers and geobarometers point to different P-T-t paths in the hanging-wall and footwall rocks of the MSZ. Whereas the temperatures registered in the hanging-wall and in the footwall are pretty similar the difference in pressure is at least $0.2 \mathrm{GPa}$. This means that the activity of the MSZ for nearly $7 \mathrm{Ma}$ affected the metamorphic evolution of the GHS at the point that the hanging-wall rocks underwent a lower pressure ( 0.2 GPa) with respect to the footwall rocks. In this frame the MSZ was responsible for the exhumation of part of GHS rocks (i.e. the hanging-wall of the MSZ) in the 25-18 Ma time span.

Peak metamorphic conditions were reached at $\sim 25 \mathrm{Ma}$ in the upper part of GHS whereas in the lower part of GHS were reached only 5-7 Ma later, at $17 \mathrm{Ma}$ (the ages of low Y domain Mnz2 $2_{\mathrm{FW}}$ ). Geochronological results coupled with field, textural and geothermobarometers information points out an important result on the P-T-t history of GHS rocks. In the same time span while Mnz from hanging-wall had a retrograde path (high Y + HREE domains in monazite), the footwall monazites show a prograde growth history with low Y + HREE domains.

These observations point out a diachronisms in the metamorphisms (and shearing) between the samples from the upper and the lower GHS.

The results are well-comparable for the same structural level with the ones obtained for an analogous shear zone reported by Carosi et al. $(2007,2010)$ within the analytical errors, in Western Nepal.

\subsection{Regional occurrence of tectono-metamorphic discontinuities in the} GHS

Swapp and Hollister (1991) and Harris and Massey (1994) proposed the occurrence of a metamorphic discontinuity at the sillimanite/kyanite isograd between the upper part of the GHS with sillimanite from the lower part with kyanite in Eastern and in Central Himalayas (Langtang section), respectively.

In Central and Eastern Nepal the presence of metamorphic discontinuities have been inferred based only by differences in the P-T-t paths of hanging-wall and footwall rocks but without detecting kinematic indicators e.g., Langtang (Fraser et al., 2000; Kohn, 2008; Kohn et al., 2005; Macfarlane, 1993; Reddy et al., 1993), Annapurna massif (Corrie and Kohn, 2011; Martin et al., 2010) and Arun valley (Groppo et al., 2009). The kinematics has been inferred by difference in metamorphic grade leading to interpret the metamorphic discontinuities both as contractional or normal sense shear zones. However, without clear kinematic indicators several mechanisms (both compressive and extensional) could account for the difference in metamorphic grade of hanging-wall and footwall rocks (Carosi et al., 2010). Since the shape of $\mathrm{P}-\mathrm{T}-\mathrm{t}$ path and the absolute $\mathrm{P}-\mathrm{T}$ values at peak conditions are not distinctive for a particular exhumation mechanism in collisional orogens, they should be used in combination with geochronological and structural constrains.

In the last few years further studies progressively added structural, metamorphic and geochronological evidences of such a metamorphic discontinuity stretching from India, Western Nepal (Carosi et al., 2007, 2010; Yakymchuck and Godin, 2012) to Nepal-Sikkim (Goscombe et al., 2006; Imayama et al., 2010, 2012; Rubatto et al., 2012) for more than $500 \mathrm{~km}$ along strike of the belt (Carosi et al., 2012).

The kinematic, geochronological and P-T-t data from the Mangri Shear Zone are in good agreement with the ones obtained for the Tojiem shear zone, localized within the GHS nearly $40 \mathrm{~km}$ southeastward of the study area (Carosi et al., 2007, 2010).

Considering the tectonometamorphic discontinuity reported at a wider scale along the belt (Figs. 2, 3) in the nearby Karnali area to the NW (Yakymchuck and Godin, 2012), the Mangri and the Tojiem shear zones in the Jumla and Mugu-Karnali areas, the metamorphic discontinuity in Himalaya to the East of the study area (Larson et al., 2010, 2011) and the ones recognised in Eastern Nepal (Goscombe et al., 2006; Groppo et al., 2009; Imayama et al., 2010, 2012) and Sikkim (Rubatto et al., 2012) it is evident that the core of the GHS is characterised by a major tectonic and metamorphic discontinuity for several hundreds of $\mathrm{km}$ along strike of the belt allowing shearing and exhumation of GHS rocks in a time span from 28-26 to $17 \mathrm{Ma}$. We refer it in general as the High Himalayan Discontinuity since it is not a simple thrust because it exhibits a ductile behaviour. But also the term "shear zone" could be reductive considering the large occurrence of metamorphic discontinuities without occurrence of well-expressed shear zones ("hidden discontinuities"). On the other hand not all the thrusts or shear zones can cause a difference of metamorphism between hanging-wall and footwall. The use of the term "discontinuity" is intended to be comprehensive for both tectonic features (both ductile and brittle shear zones and related kinematic indicators) and detectable metamorphic differences between hanging-wall and footwall triggered by it.

In addition, by connecting the tectonic-metamorphic discontinuities in Central and Eastern Himalaya (Fig. 2) it is evident the regional occurrence of High Himalayan Discontinuity, roughly at the same level in the GHS, separating the sillimanite-bearing gneiss and schist in the upper part of the GHS $\left(\mathrm{GHS}_{\mathrm{U}}\right.$, Larson et al., 2010) from the kyanite bearing gneiss and schists in the lower part $\left(\mathrm{GHS}_{\mathrm{L}}\right.$, Larson et al., 2010). The finding of a tectono-metamorphic discontinuity in the middle of the GHS allow the separation of the GHS in two distinct portions: the upper GHS $\left(\mathrm{GHS}_{\mathrm{U}}\right)$ and the lower GHS $\left(\mathrm{GHS}_{\mathrm{L}}\right)$.

This regional tectonic-metamorphic discontinuity triggered the earlier exhumation of the $\mathrm{GHS}_{\mathrm{U}}$, before the classical onset of MCT (Carosi et al., 2010; Imayama et al., 2012). Tectonic discontinuities within the GHS have been regarded in most cases as out of sequence thrusts with respect to MCT (Mukherjee et al., 2011). Our study demonstrates the wide occurrence of in-sequence ductile shear zones active before MCT and the limiting occurrence of out of sequence thrusts in Central Himalayas.

\subsection{Consequences for exhumation mechanisms of the GHS}

A decreasing pressure going upward in the GHS has been observed by several authors (Beaumont et al., 2001; Groppo et al., 2009; Imayama et al., 2012; Yakymchuck and Godin, 2012) and it is usually interpreted to confirm, or at least to be in agreement, with channel flow model PT predictions (Jamieson et al., 2004). However, this feature alone is not diagnostic for channel flow model because other tectonic mechanisms can well account for such a pressure pattern (Carosi et al., 2010; Imayama et al., 2012). Rubatto et al. (2012) emphasised that even if the shape of P-T-t paths is similar to those predicted by channel flow, their timing is different. 
In addition to this, the tectono-metamorphic discontinuity caused a different behaviour of the $\mathrm{GHS}_{\mathrm{U}}$ and $\mathrm{GHS}_{\mathrm{L}}$ as well as their different exhumation timing. The $\mathrm{GHS}_{\mathrm{U}}$ and $\mathrm{GHS}_{\mathrm{L}}$ reached maximum $\mathrm{P}$ and $\mathrm{T}$ conditions in different times and were exhumed with a difference of nearly 5 Myr.

These data are not in agreement with channel flow and wedge extrusion models of exhumation for the GHS because both models require the contemporaneous activity of the STD and MCT for several Myr (Fig. 1). The two models predict that all the GHS underwent the same tectono-metamorphic behaviour as a coherent unit and it was exhumed at the same time, at least in sections perpendicular to the main tectonic boundaries.

A contemporaneous activity of the MCT and STDS is predicted also by the wedge insertion model (Webb et al., 2007), with the MCT and STD tapering towards the South developing a leading edge geometry, so that the GHS is exhumed as a unique coherent tectonic unit (Fig. 1). The MSZ divides the GHS in two different tectonic slices that cannot be easily included in this model unless we consider the MCT equivalent to MSZ, and that it is not the case both for the structural position and timing. Anyway the wedge geometry of the upper GHS, delimited by the MSZ at the bottom and the STD to the top, needs to be demonstrated.
The critical taper (Kohn, 2008) model (Fig. 1), considering the Himalayas as a Coulomb wedge (Davis et al., 1983; Platt, 1993) explains normal faulting along the STD as a consequence of vertical overthickening caused by underplating. It is worth to note that differently from channel flow or wedge extrusion in the critical taper model STD and MCT are not contemporaneous but they alternate in motion (see also Chambers et al., 2011). This model could explain the occurrence of thrusts above the MCT in the inner part of the belt, as a response to the thinning of the wedge, but only as out-of-sequence thrusts, i.e. active after the motion of the MCT. However, the MSZ is not an out-of-sequence thrust because our geochronological data demonstrate that it is nearly $5 \mathrm{Myr}$ older than the MCT across the same section. For this reason our data cannot support the critical taper model.

Moreover, the progressive activation of shear zones from the upper and inner part of the GHS toward the lower and external part is in agreement with the progressive incorporation in the belt of crustal slices from the Indian continent. In this picture progressive new slices are incorporated in the belt by underthrusting. In this stage they reach their maximum $\mathrm{P}$ and $\mathrm{T}$ conditions. When a new shear zone or thrust is activated in front of the last incorporated slice it became exhumed as the hanging-wall moves up to the foreland.
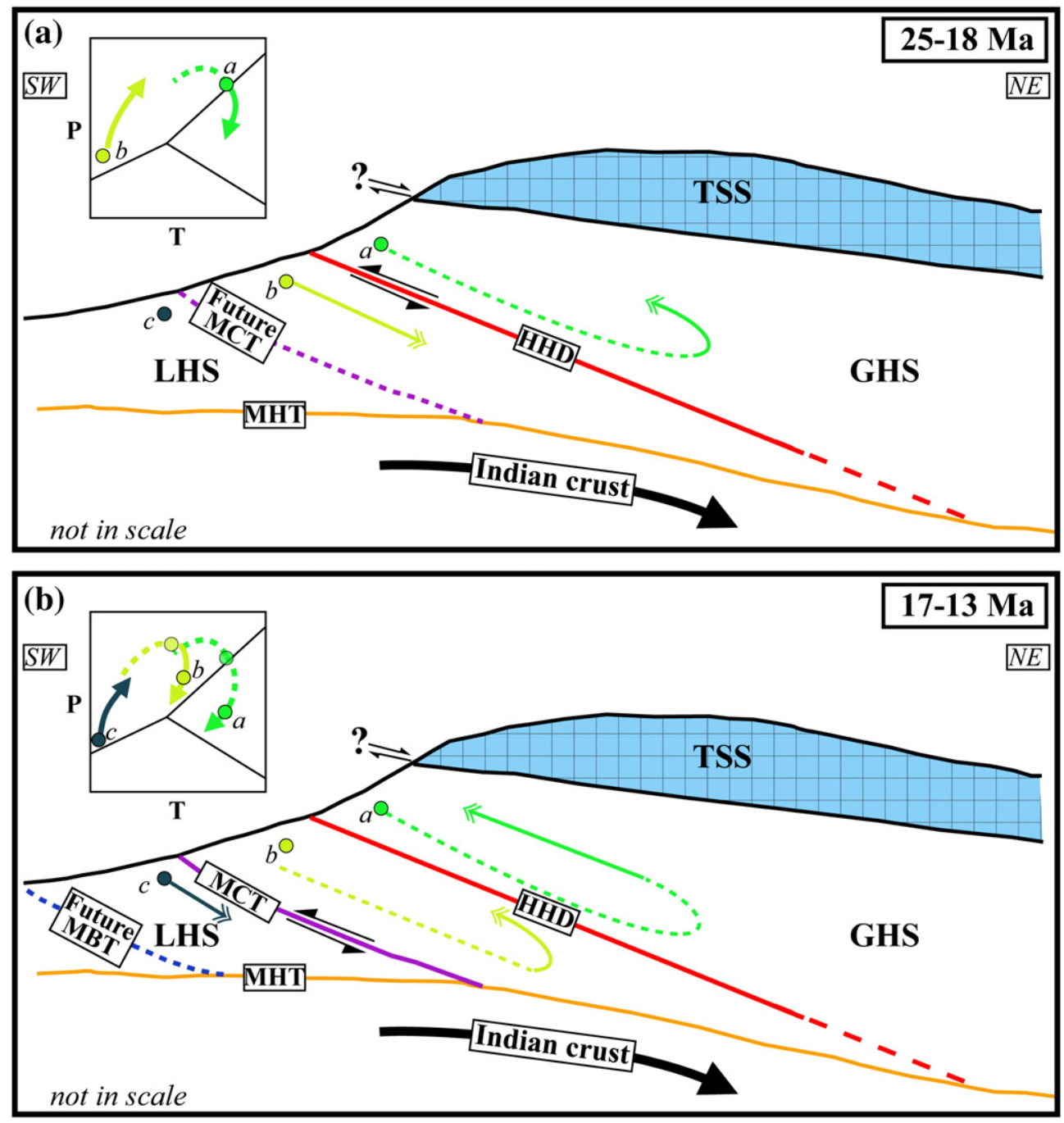

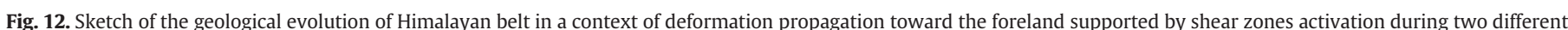

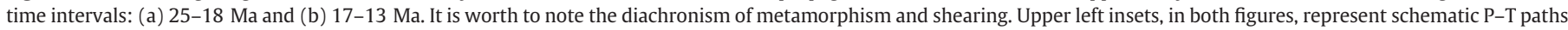

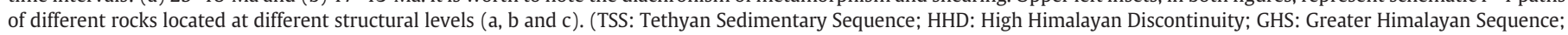
LHS: Lesser Himalayan Sequence; MCT: Main Central Thrust; MBT: Main Boundary Thrust; MHT: Main Himalayan Thrust). 
Moreover, contractional shear zones occurring in the core of GHS for several hundred kilometres along strike could account for the lower pressure recorded in the upper part of the GHS tectonic unit (e.g. Beaumont et al., 2001). To explain this we have to take into consideration the complex interplay between the activation of shear zones in the GHS and the overall exhumation pattern of the GHS (Carosi et al., 2010). Geochronology investigation on Mnz and Zrn points to an activity between $\sim(28) 26$ and $17 \mathrm{Ma}$. This time span is crucial because it falls both in the underthrusting stage of the GHS and in its exhumation stage between 23 and $17 \mathrm{Ma}$. On initial activation of the main contractional shear zone in the middle part of the GHS the hanging-wall rocks started to exhume after they reached their maximum depth whereas footwall rock continued to be buried reaching higher pressure with respect to hanging-wall rocks. When all the GHS underwent exhumation all the rocks within it moved toward the surface. However, the displacement of rocks caused by the overall exhumation partly overlies to the displacement caused by the older shear zone leading to different velocities in the paths of the hanging-wall and footwall rocks, being the higher velocities of exhumation in the hanging-wall. In the latter case the velocity of the shear zone summed up to the velocity of the overall exhumation path, whereas in the former velocity the shear zone goes into contrast with the velocity of the overall exhumation, causing a decreasing exhumation velocity.

Larson et al. (2010) and Yakymchuck and Godin (2012) regard the tectono-metamorphic discontinuity in the GHS as a boundary between the upper hot channel and a lower portion of the GHS undergoing extrusion so that they limit the thickness of the channel to the GHS structurally located above the regional shear zone.

However, this restriction of the hot channel causes problems in the required minimum thickness to activate a channel flow, well below the $20-30 \mathrm{~km}$ indicated as necessary by Beaumont et al. (2001) and Godin et al. (2006).

These results and considerations are in keeping with the recent finding of undeformed leucogranite intruding both the GHS and TSS at 23-24 Ma close to the study area (Bertoldi et al., 2011; Carosi et al., in press), limiting to a very short time span the simultaneous movement of STD and MCT in the study area (Carosi et al., 2012). So that if extrusion and channel flow played a role in the exhumation of the GHS it was for a very short time span.

We conclude that exhumation of GHS rocks in Central Himalayas was driven by ductile shear zones within its core starting from 26 up to $17 \mathrm{Ma}$. Older shear zones (Higher Himalayan Thrust) up to $\sim 28 \mathrm{Ma}$ with the same meaning have been reported in Eastern Nepal by Imayama et al. (2012).

The activation of lower ductile shear zones in the footwall of the MSZ at 17-13 Ma testifies a progressive migration of shearing from the middle part of the GHS to the lower zone (Fig. 12). This causes the rocks of the upper GHS to reach peak metamorphic conditions at 26-25 Ma, i.e. 5-8 Ma earlier with respect to the rocks of the lower GHS reaching their climax at 20-18 Ma. The proposed mechanism progressively involves slices of continental crust that reach peak conditions during burial and are exhumed in meanwhile a shear zone is activated to its base and the lower slice in the footwall undergoes burial following a very similar path, but shifted some Ma later (Fig. 12).

The new structural, thermobarometric and geochronological data confirm that GHS is not a single tectonic unit in which P and T were reached simultaneously everywhere (even if $\mathrm{P}-\mathrm{T}-\mathrm{t}$ paths exhibit the same shape, as suggested also by Rubatto et al., 2012) but there is a regional tectonic and metamorphic discontinuity (the High Himalayan Discontinuity, Fig. 12) and a younging direction of the structural and metamorphic processes to the south and southwest.

The presented structural, metamorphic and geochronological data leave no enough room for channel flow model of exhumation models of exhumation in a large part of the Central Himalayan belt.

\section{Conclusions}

In this paper we documented the occurrence of a prominent ductile and high-temperature contractional shear zone within the GHS, showing a top-to-the-SW sense of shear, producing a thickness of nearly $4 \mathrm{~km}$ of mylonites.

$\mathrm{U}-\mathrm{Pb}$ dating on monazites crystallized along the mylonitic foliation suggests a continuous activity of the shear zone between 25 and $17 \mathrm{Ma}$ pointing out that the MSZ cannot be interpreted as an out of sequence thrust. Moreover an in-sequence activation of ductile shear zones is proved by the $\sim 20$ Ma deformation age of the samples in the lower part of the GHS, in the footwall of the MSZ.

Rocks from the MSZ registered pressures around $0.7 \mathrm{GPa}$ whereas footwall rock underwent a pressure of 1.0-0.9 GPa showing a pressure difference of at least $0.2 \mathrm{GPa}$. Geochronology suggests that peak metamorphic conditions were reached $\sim 5$ Myr later in the footwall of the MSZ with respect to the hanging-wall, pointing out a diachronisms in the metamorphisms triggered by the shear zones itself.

MSZ together with the other recently documented discontinuities in the GHS testifies to the occurrence of a regional tectonic and metamorphic discontinuity in Central Himalayas: the High Himalayan Discontinuity. The High Himalayan Discontinuity was responsible of the exhumation of the upper part of the GHS starting from $28 \mathrm{Ma}$ (Imayama et al., 2012) well before the initiation of the activity of the MCT and the STD.

Exhumation mechanisms based on the contemporaneous activity of MCT and STD, such as channel flow and ductile extrusion, played a secondary role in the exhumation of crystalline rocks of the GHS. Moreover the occurrence of partially molten rocks having a thickness of 20-30 km and flowing at 23-17 Ma have not been confirmed in the study area, ruling out a major role of the channel flow mechanism in this part of the orogen.

The new acquired data point to a progressive migration of deformation and metamorphism with activation of progressively younger shear zones in the GHS to the south and southwest (Fig. 12).

Exhumation of the GHS didn't happen at the same time everywhere but it was partitioned in space and time and different slices were exhumed in different times, starting from the older in the upper part to the younger in the lower one.

\section{Acknowledgements}

We thank the editor Prof. Mian Liu, Prof. A. Steck and an anonymous reviewer for their constructive comments which greatly improved this manuscript.

Research supported by PRIN 2010-2011 (R. Carosi and C. Montomoli) and Torino University (R. Carosi), Pisa University (C. Montomoli) and Padova University (D. Visonà).

\section{Appendix 1}

Samples used for P-T estimations were chosen according to the textural equilibrium among phases. In order to take the garnet composition closer to the highest metamorphic grade, we used Grt composition with the lowest $\mathrm{Fe} /(\mathrm{Fe}+\mathrm{Mg}$ ) and $\mathrm{Mn}$ content (rim/near rim position) and then combine with matrix phases.

$\mathrm{Wu}$ et al. (2004) reported two GBPQ barometers model (Mgand Fe models) and Wu and Zhao (2006) reported four different calibration for the GMPQ Mg- and Fe-,each of one split in two models to account iron oxidation state in Ms ( $0 \%$ and $50 \%$ of total iron as $\mathrm{Fe}^{3+}$ ). We observed no substantial difference in the $\mathrm{P}$ values reported (less than $0.01-0.03 \mathrm{GPa}$ ), so an average $\mathrm{P}$ value is presented. 
Appendix 2. Table of Moacir standards

\begin{tabular}{|c|c|c|c|c|c|c|c|c|c|c|c|c|c|c|c|c|c|}
\hline \multirow[t]{2}{*}{ Analysis } & \multirow[t]{2}{*}{ Position } & \multicolumn{8}{|c|}{ Isotopic ratios } & \multicolumn{8}{|l|}{ Ages } \\
\hline & & $\begin{array}{l}{ }^{207} \mathrm{~Pb} / \\
{ }^{208} \mathrm{~Pb}\end{array}$ & $1 \sigma \%$ & $\begin{array}{l}{ }^{206} \mathrm{~Pb} / \\
{ }^{238} \mathrm{U}\end{array}$ & $1 \sigma \%$ & $\begin{array}{l}{ }^{207} \mathrm{~Pb} / \\
{ }^{235} \mathrm{U}\end{array}$ & $1 \sigma \%$ & $\begin{array}{l}{ }^{208} \mathrm{~Pb} / \\
{ }^{232} \mathrm{Th}\end{array}$ & $1 \sigma \%$ & $\begin{array}{l}{ }^{207} \mathrm{~Pb} / \\
{ }^{208} \mathrm{~Pb}\end{array}$ & $1 \sigma \%$ & $\begin{array}{l}{ }^{206} \mathrm{~Pb} / \\
{ }^{238} \mathrm{U}\end{array}$ & $\begin{array}{l}1 \sigma \\
\text { (abs) }\end{array}$ & $\begin{array}{l}{ }^{207} \mathrm{~Pb} / \\
{ }^{235} \mathrm{U}\end{array}$ & $\begin{array}{l}1 \sigma \\
\text { (abs) }\end{array}$ & $\begin{array}{l}{ }^{208} \mathrm{~Pb} / \\
{ }^{232} \mathrm{Th}\end{array}$ & $\begin{array}{l}1 \sigma \\
\text { (abs) }\end{array}$ \\
\hline \multicolumn{18}{|l|}{ I run } \\
\hline De13a002 & Begin & 0.05551 & $0.12 \%$ & 0.08278 & $0.13 \%$ & 0.63343 & $1.25 \%$ & 0.02523 & $0.04 \%$ & 433 & 27 & 513 & 7 & 498 & 6 & 504 & 7 \\
\hline De13a003 & Begin & 0.05758 & $0.12 \%$ & 0.08226 & $0.13 \%$ & 0.65281 & $1.27 \%$ & 0.02527 & $0.04 \%$ & 514 & 26 & 510 & 7 & 510 & 6 & 504 & 7 \\
\hline De13a018 & Middle & 0.05685 & $0.12 \%$ & 0.08250 & $0.12 \%$ & 0.64644 & $1.23 \%$ & 0.02557 & $0.04 \%$ & 523 & 29 & 511 & 7 & 506 & 5 & 510 & 6 \\
\hline De13a019 & Middle & 0.05543 & $0.12 \%$ & 0.08329 & $0.12 \%$ & 0.63611 & $1.22 \%$ & 0.02529 & $0.04 \%$ & 437 & 30 & 516 & 7 & 500 & 5 & 505 & 6 \\
\hline De13a020 & Middle & 0.05691 & $0.12 \%$ & 0.08224 & $0.12 \%$ & 0.64515 & $1.22 \%$ & 0.02487 & $0.04 \%$ & 485 & 26 & 510 & 7 & 506 & 5 & 496 & 6 \\
\hline De13a037 & End & 0.05783 & $0.13 \%$ & 0.08212 & $0.12 \%$ & 0.65437 & $1.30 \%$ & 0.02523 & $0.04 \%$ & 429 & 26 & 509 & 7 & 511 & 6 & 504 & 6 \\
\hline De13a038 & End & 0.05561 & $0.13 \%$ & 0.08295 & $0.12 \%$ & 0.63564 & $1.28 \%$ & 0.02530 & $0.04 \%$ & 488 & 25 & 514 & 7 & 500 & 6 & 505 & 6 \\
\hline \multicolumn{18}{|l|}{ II run } \\
\hline De13i001 & Begin & 0.05652 & $0.23 \%$ & 0.08276 & $0.17 \%$ & 0.02985 & $2.22 \%$ & 0.02497 & $0.04 \%$ & 472 & 48 & 513 & 7 & 506 & 9 & 499 & 6 \\
\hline De13i002 & Begin & 0.05489 & $0.22 \%$ & 0.08122 & $0.17 \%$ & 0.02875 & $2.32 \%$ & 0.02515 & $0.04 \%$ & 408 & 50 & 503 & 7 & 487 & 9 & 502 & 6 \\
\hline De13i003 & Begin & 0.05777 & $0.23 \%$ & 0.08345 & $0.17 \%$ & 0.03041 & $2.11 \%$ & 0.02555 & $0.04 \%$ & 521 & 45 & 517 & 7 & 518 & 9 & 510 & 6 \\
\hline De13i020 & Middle & 0.05619 & $0.23 \%$ & 0.08065 & $0.17 \%$ & 0.02939 & $2.38 \%$ & 0.02525 & $0.04 \%$ & 459 & 51 & 500 & 7 & 493 & 9 & 504 & 6 \\
\hline De13i021 & Middle & 0.05805 & $0.24 \%$ & 0.08390 & $0.17 \%$ & 0.03168 & $2.40 \%$ & 0.02535 & $0.04 \%$ & 531 & 52 & 519 & 7 & 522 & 10 & 506 & 6 \\
\hline De13i022 & Middle & 0.0555 & $0.23 \%$ & 0.08350 & $0.17 \%$ & 0.03048 & $2.51 \%$ & 0.02510 & $0.04 \%$ & 432 & 54 & 517 & 7 & 502 & 10 & 501 & 6 \\
\hline De13i047 & End & 0.0578 & \#REF! & 0.08203 & $0.17 \%$ & 0.03136 & $2.56 \%$ & 0.02501 & $0.04 \%$ & 522 & 56 & 508 & 7 & 511 & 10 & 499 & 6 \\
\hline De13i048 & End & 0.05278 & \#REF! & 0.08211 & $0.17 \%$ & 0.02883 & $2.62 \%$ & 0.02505 & $0.04 \%$ & 319 & 58 & 509 & 7 & 493 & 9 & 500 & 6 \\
\hline De13i049 & End & 0.05783 & \#REF! & 0.08454 & $0.18 \%$ & 0.03247 & $2.60 \%$ & 0.02546 & $0.04 \%$ & 523 & 56 & 523 & 7 & 522 & 10 & 508 & 6 \\
\hline De13i050 & End & 0.0594 & \#REF! & 0.08157 & $0.17 \%$ & 0.03220 & $2.60 \%$ & 0.02549 & $0.04 \%$ & 582 & 56 & 506 & 7 & 502 & 10 & 509 & 6 \\
\hline \multicolumn{18}{|l|}{ III run } \\
\hline Jl05a001 & Begin & 0.05665 & $0.16 \%$ & 0.08326 & $0.14 \%$ & 0.64978 & $1.84 \%$ & 0.02582 & $0.04 \%$ & 477 & 26 & 516 & 8 & 508 & 6 & 515 & 6 \\
\hline Jl05a002 & Begin & 0.05629 & $0.16 \%$ & 0.08262 & $0.14 \%$ & 0.64076 & $1.82 \%$ & 0.02527 & $0.04 \%$ & 463 & 27 & 512 & 7 & 503 & 6 & 504 & 5 \\
\hline Jl05a003 & Begin & 0.05451 & $0.16 \%$ & 0.08262 & $0.14 \%$ & 0.62045 & $1.76 \%$ & 0.02514 & $0.04 \%$ & 392 & 27 & 512 & 7 & 490 & 6 & 502 & 5 \\
\hline Jl05a004 & Begin & 0.05921 & $0.17 \%$ & 0.08149 & $0.14 \%$ & 0.66482 & $1.88 \%$ & 0.02471 & $0.04 \%$ & 575 & 26 & 505 & 7 & 518 & 6 & 493 & 5 \\
\hline Jl05a029 & End & 0.05689 & $0.17 \%$ & 0.08208 & $0.14 \%$ & 0.64362 & $1.85 \%$ & 0.02536 & $0.04 \%$ & 487 & 29 & 509 & 7 & 505 & 6 & 506 & 5 \\
\hline Jl05a030 & End & 0.05812 & $0.17 \%$ & 0.08272 & $0.14 \%$ & 0.66266 & $1.90 \%$ & 0.02532 & $0.04 \%$ & 534 & 29 & 512 & 7 & 516 & 6 & 505 & 5 \\
\hline Jl05a031 & End & 0.05529 & $0.16 \%$ & 0.08220 & $0.14 \%$ & 0.62650 & $1.80 \%$ & 0.02491 & $0.04 \%$ & 424 & 29 & 509 & 7 & 494 & 6 & 497 & 5 \\
\hline $\mathrm{Jl} 105 \mathrm{a} 032$ & End & 0.0559 & $0.17 \%$ & 0.08331 & $0.14 \%$ & 0.64190 & $1.80 \%$ & 0.02547 & $0.04 \%$ & 448 & 29 & 516 & 7 & 504 & 6 & 508 & 5 \\
\hline \multicolumn{18}{|l|}{ IV run } \\
\hline Oc02a002 & Begin & 0.05504 & $0.06 \%$ & 0.08376 & $0.08 \%$ & 0.63392 & $0.62 \%$ & 0.02523 & $0.03 \%$ & 414 & 19 & 499 & 19 & 519 & 8 & 504 & 6 \\
\hline Oc02a003 & Begin & 0.05595 & $0.06 \%$ & 0.0824 & $0.07 \%$ & 0.63390 & $0.64 \%$ & 0.02538 & $0.03 \%$ & 450 & 21 & 499 & 19 & 510 & 8 & 507 & 6 \\
\hline Oc02a004 & Begin & 0.06011 & $0.07 \%$ & 0.08094 & $0.07 \%$ & 0.66903 & $0.67 \%$ & 0.02514 & $0.03 \%$ & 608 & 28 & 520 & 20 & 502 & 8 & 502 & 6 \\
\hline Oc02a022 & End & 0.05884 & $0.07 \%$ & 0.0828 & $0.08 \%$ & 0.67127 & $0.79 \%$ & 0.02507 & $0.03 \%$ & 561 & 26 & 521 & 20 & 513 & 8 & 500 & 6 \\
\hline Oc02a023 & End & 0.05401 & $0.07 \%$ & 0.08283 & $0.08 \%$ & 0.61644 & $0.73 \%$ & 0.02543 & $0.03 \%$ & 371 & 18 & 488 & 19 & 513 & 8 & 508 & 6 \\
\hline \multicolumn{18}{|l|}{ V run } \\
\hline Oc02b001 & Begin & 0.05555 & $0.07 \%$ & 0.08210 & $0.07 \%$ & 0.62893 & $0.67 \%$ & 0.02517 & $0.02 \%$ & 434 & 9 & 495 & 11 & 509 & 7 & 502 & 6 \\
\hline Oc02b002 & Begin & 0.05772 & $0.07 \%$ & 0.08327 & $0.07 \%$ & 0.66266 & $0.72 \%$ & 0.02530 & $0.02 \%$ & 519 & 11 & 516 & 11 & 516 & 7 & 505 & 6 \\
\hline Oc02b019 & End & 0.05751 & $0.07 \%$ & 0.08170 & $0.08 \%$ & 0.64766 & $0.74 \%$ & 0.02552 & $0.03 \%$ & 511 & 11 & 507 & 11 & 506 & 7 & 509 & 6 \\
\hline Oc02b020 & End & 0.05632 & $0.07 \%$ & 0.08231 & $0.08 \%$ & 0.63891 & $0.75 \%$ & 0.02526 & $0.03 \%$ & 465 & 10 & 502 & 11 & 510 & 7 & 504 & 6 \\
\hline Oc02b022 & End & 0.05571 & $0.07 \%$ & 0.08360 & $0.08 \%$ & 0.64208 & $0.77 \%$ & 0.02500 & $0.03 \%$ & 441 & 10 & 504 & 11 & 518 & 7 & 499 & 6 \\
\hline
\end{tabular}

\section{References}

Antolín, B., Appel, A., Montomoli, C., Dunkl, I., Ding, L., Gloaguen, R., El Bay, R., 2011. Kinematic evolution of the eastern Tethyan Himalaya: constraints from magnetic fabric and structural properties of the Triassic flysch in SE Tibet. In: Poblet, J., Lisle, R. (Eds.), Kinematic Evolution and Structural Styles of Fold-and-Thrust Belts: Geological Society of London Special Publications, 349, pp. 99-121. http://dx.doi.org/10.1144/SP349.6.

Beaumont, C., Jamieson, R.A., Nguyen, M.H., Lee, B., 2001. Himalayan tectonics explained by extrusion of a low-viscosity crustal channel coupled to focused surface denudation. Nature 414, 738-742.

Bertoldi, L., Massironi, M., Visonà, D., Carosi, R., Montomoli, C., Gubert, F., Naletto, G., Pelizzo, M.G., 2011. Mapping the Buraburi granite in the Himalaya of Western Nepal: remote sensing analysis in a collisional belt with vegetation cover and extreme variation of topography. Remote Sensing of Environment 115, 1129-1144.

Burchfiel, B.C., Chen, Z., Hodges, K.V., Liu, Y., Royden, L.H., Changrong, D., Xu, L., 1992. The South Tibetan Detachment System, Himalayan Orogen: extension contemporaneous with and parallel to shortening in a collisional mountain belt. Geological Society of America Special Paper 269, 1-41.

Burg, J.P., Brunel, M., Gapais, D., Chen, G.M., Liu, G.H., 1984. Deformation of leucogranites of the crystalline Main Central Sheet in southern Tibet (China). Journal of Structural Geology 6, 535-542.

Caby, R., Pêcher, A., Le Fort, P., 1983. Le grand chevauchement central himalayen: Nouvelles données sur le métamorphisme inverse à la base de la Dalle du Tibet. Revue de Géologie Dynamique et de Géographie Physique 24, 89-100.

Carosi, R., Lombardo, B., Molli, G., Musumeci, G., Pertusati, P.C., 1998. The south Tibetan detachment system in the Rongbuk valley, Everest Region. Deformation features and geological implication. Journal of Asian Earth Sciences 16, 299-311.
Carosi, R., Montomoli, C., Visonà, D., 2002. Is there any detachment in the Lower Dolpo (Western Nepal)? Comptes Rendus Geosciences 334, 933-940.

Carosi, R., Montomoli, C., Visonà, D., 2007. A structural transect in the Lower Dolpo: insights on the tectonic evolution of Western Nepal. Journal of Asian Earth Sciences 29, 407-423.

Carosi, R., Montomoli, C., Rubatto, D., Visonà, D., 2010. Late Oligocene high-temperature shear zones in the core of the Higher Himalayan Crystallines (Lower Dolpo, Western Nepal). Tectonics 29, TC4029. http://dx.doi.org/10.1029/2008TC002400.

Carosi, R., Montomoli, C., Iaccarino, S., Rubatto, D., Visonà, D., 2012. Was the exhumation of the Greater Himalayan Sequence totally driven by STD and MCT? 27th Himalaya-Karakoram-Tibet Workshop, Kathmandu (Nepal), November 28-30, 2012, pp. 212-213.

Carosi, R., Montomoli, C., Rubatto, D., Visonà, D., 2013. Leucogranite intruding the South Tibetan Detachment in Western Nepal: implications for exhumation models in the Himalayas. Terra Nova (in press)

Chambers, J., Parrish, R., Argles, T., Harris, N., 2011. A short-duration pulse of ductile normal shear on the outer South Tibetan detachment in Bhutan: alternating channel flow and critical taper mechanics of the eastern Himalaya. Tectonics 3, TC2005

Chemenda, A.I., Mattauer, M., Malavieille, J., Bokun, A.N., 1995. A mechanism for syncollisional rock exhumation and associated normal faulting: results from physical modelling. Earth and Planetary Science Letters 132, 225-232.

Cipriani, C., Sassi, F.P., Scolari, A., 1971. Metamorphic white micas: definition of petrogenetic fields. Schweizerische Mineralogische und Petrographische Mitteilungen 51, 259-302.

Corrie, S.L., Kohn, M.J., 2011. Metamorphic history of the Central Himalaya, Annapurna region, Nepal, and implication for tectonic models. Geological Society of American Bulletin 123, 1863-1879. 
Cottle, J.M., Searle, M.P., Horstwood, M.S.A., Waters, D.J., 2009. Timing of midcrusta metamorphism, melting and deformation in the Mount Everest Region of Southern Tibet revealed by U-(Th)-Pb geochronology. The Journal of Geology 117, 643-664.

Crouzet, C., Dunkl, I., Paudel, L., Arkai, P., Rainer, T.M., Balogh, K., Appel, E., 2007. Temperature and age constraints on the metamorphism of the Tethyan Himalaya in Central Nepal: a multidisciplinary approach. Journal of Asian Earth Sciences 30, 113-130.

Cruz, M.J., Cunha, J.C., Merlet, C., Sabaté, P., 1996. Dataçao pontual das monazitas da regiao de Itambé, Bahia, através da microssonda electrônica. XXXIX Congresso Brasileiro de Geologia, pp. 206-209.

Daniel, C.G., Hollister, L., Parrish, R.R., Grujic, D., 2003. Exhumation of the Main Centra thrust from lower crustal depths, Eastern Bhutan Himalaya. Journal of Metamorphic Geology 21, 317-334.

Davidson, C., Grujic, D., Hollister, L., Schmid, S.M., 1997. Metamorphic reaction related to decompression and synkinematic intrusion of leucogranite, High Himalayan Crystallines, Bhutan. Journal of Metamorphic Geology 15, 593-612.

Davis, D., Suppe, J., Dahlen, F.A., 1983. Mechanics of fold-and-thrust belts and accretionary wedges. Journal of Geophysical Research 88 (B2), 1153-1178.

Dumond, G., McLean, N., Williams, M.L., Jercinovic, M.J., Bowring, S.A., 2008. Highresolution dating of granite petrogenesis and deformation in a lower crusta shear zone: Athabasca granulite terrane, western Canadian Shield. Chemica Geology 254, 175-196.

Dunkl, I., Antolín, B., Wemmer, K., Rantitsch, G., Kienast, M., Montomoli, C., Ding, L, Carosi, R., Appel, E., El Bay, R., Xu, Q., von Eynatten, H., 2011. Metamorphic evolution of the Tethyan Himalayan flysch in SE Tibet. In: Gloaguen, R., Ratschbacher, L (Eds.), Growth and Collapse of the Tibetan Plateau: Geological Society of London Special Publications, 353, pp. 45-69. http://dx.doi.org/10.1144/SP353.4.

Foster, G., Parrish, R.R., 2003. Metamorphic monazite and generation of P-T-t paths. Geological Society of London Special Publication 220, 25-47.

Foster, G., Kinny, P., Vance, D., Prince, C., Harris, N., 2000. The significance of monazite $\mathrm{U}-\mathrm{Th}-\mathrm{Pb}$ age data in metamorphic assemblages; a combined study of monazite and garnet chronometry. Earth and Planetary Science Letters 181, 327-340.

Frank, W., Fuchs, G.R., 1970. Geological investigation in Western Nepal and their significance for the geology of the Himalayas. Geologische Rundschau 59, 552-580.

Fraser, G., Worley, B., Sandiford, M., 2000. High-precision geothermobarometry across the High Himalayan metamorphic sequences, Langtang valley, Nepal. Journal of Metamorphic Geology 18, 665-685.

Gansser, A., 1964. Geology of Himalayas.Wiley Interscience, London 289.

Gasquet, D., Bertrand, J.-M., Paquette, J.-L., Lehmann, J., Ratzov, G., De Ascençâo Guedes, R., Tiepolo, M., Boullier, A.-M., Scaillet, S., Nomade, S., 2010. Miocene to Messinian deformation and hydrothermal activity in a pre-Alpine basement massif of the French western Alps: new U-Th-Pb and argon ages from Lauzière massif. Bulletin de la Société Géologique de France 181, 227-241.

Gibson, H.D., Carr, D.S., Brown, L.R., Hamilton, A.M., 2004. Correlations between chemical and age domains in monazite, and metamorphic reactions involving major pelitic phases: an integration of ID-TIMS and SHRIMP geochronology with Y-Th-U X-ray mapping. Chemical Geology 211, 237-260.

Godin, L., Grujic, D., Law, R.D., Searle, M.P., 2006. Channel flow, ductile extrusion and exhumation in continental collision zones: an introduction. Geological Society of London Special Publication 268, 1-23.

Goscombe, B., Gray, D., Hand, M., 2006. Crustal architecture of the Himalayan metamorphic front in eastern Nepal. Gondwana Research 10, 232-255.

Groppo, C., Rolfo, F., Lombardo, B., 2009. P-T evolution across the Main Central Thrust Zone (Eastern Nepal): hidden discontinuities revealed by petrology. Journal of Petrology 50, 1149-1180.

Grujic, D., Casey, M., Davidson, C., Hollister, S.L., Kündig, R., Pavlis, T., Schmid, S., 1996 Ductile extrusion of the Higher Himalayan Crystalline in Bhutan: evidence from quartz microfabrics. Tectonophysics 260, 21-43.

Grujic, D., Warren, C.J., Wooden, J.L., 2012. Rapid synconvergent exhumation of Mioceneaged lower orogenic crust in the eastern Himalaya. Lithosphere 3, 346-366.

Harris, N., Massey, J., 1994. Decompression and anatexis of Himalayan metapelites. Tectonics 13, 1537-1546.

Heim, A., Gansser, A., 1939. Central Himalaya: geological observations of the Swiss expedition 1936. Memoir Society Helvetica Science Nature 73, 1-245.

Hodges, K.V., 2000. Tectonic of Himalaya and southern Tibet from two perspectives Geological Society of America Bulletin 112, 324-350.

Hodges, K.V., Parrish, R.R., Housh, T.B., Lux, D.R., Burchfiel, B.C., Royden, L.H., Chen, Z., 1992. Simultaneous Miocene extension and shortening in the Himalayan Orogen. Science 258, 1466-1470

Hodges, K.V., Parrish, R.R., Searle, M.P., 1996. Tectonics evolutions of the Central Annapurna Range Nepalese Himalayas. Tectonics 15, 1264-1291.

Holdaway, M.J., 2000. Application of new experimental and garnet Margules data to the garnet-biotite geothermometer. American Mineralogist 85, 881-892.

Holdaway, M.J., 2001. Recalibration of GASP geobarometer in light of recent garnet plagioclase activity models and versions of the garnet-biotite geothermometer American Mineralogist 86, 1117-1129.

Horstwood, M.S.A., Foster, G., Parrish, R.P., Noble, S.R., Nowell, G.M., 2003. Common-Pb corrected in situ U-Pb accessory mineral geochronology by LA-MC-ICP-MS. Journa of Analytical Atomic Spectrometry 18, 837-846.

Imayama, T., Takeshite, T., Arita, K., 2010. Metamorphic P-T profile and P-T path discontinuity across far-eastern Nepal Himalaya: investigation of channel flow models. Journal of Metamorphic Petrology 28, 527-549.

Imayama, T., Takeshite, T., Yi, K., Cho, D.-Y., Kitajima, K., Tsutsumi, Y., Kayama, M., Nishido, H., Okumura, T., Yagi, K., Itaya, T., Sano, Y., 2012. Two-stage partial melting and contrasting cooling history within the Higher Himalayan Crystalline Sequence in the far-eastern Nepal Himalaya. Lithos 134-135, 1-22.
Jamieson, R.A., Beaumont, C., Medvedev, S., Nguyen, M.H., 2004. Crustal channel flows: 2. Numerical models with implications for metamorphism in the Himalayan-Tibet orogen. Journal of Geophysical Research 109, B06407.

Janots, E., Engi, M., Berger, J., Allaz, J., Schwarz, O., Spandler, C., 2008. Prograde metamorphic sequence of REE minerals in pelitic rocks of the Central Alps: implications for allanite-monazite-xenotime phase relations from 250 to $610^{\circ} \mathrm{C}$. Journal of Metamorphic Geology 26, 509-526.

Jessup, M.J., Cottle, M.J., Searle, M.P., Law, R.D., Newell, D.L., Tracy, R.J., Waters, D.J., 2008. P-T-t-D paths of Everest Series schist, Nepal. Journal of Metamorphic Geology 26, 717-739.

Kellett, D.A., Grujic, D., Warren, C., Cottle, J., Jamieson, R., Tenzin, T., 2010. Metamorphic history of a syn-convergent orogen parallel detachment: the South Tibetan detachment system, Bhutan Himalaya. Journal of Metamorphic Geology 28, 785-808.

Kohn, M.J., 2008. P-T-t data from Nepal support critical taper and repudiate large channel flow of the Greater Himalayan Sequence. Geological Society of America Bulletin 120, 259-273.

Kohn, M.J., Spear, F.S., 2000. Retrograde net transfer reactions (ReNTR) insurance for P-T estimates. Geology 28, 1127-1130.

Kohn, M.J., Vervoort, J.D., 2008. U-Th-Pb dating of monazite by single-collector ICP-MS: pitfalls and potential. Geochemistry, Geophysics, Geosystems 9, Q0431. http://dx.doi.org/10.1029/2007GC001899.

Kohn, M.J., Wielnand, M., Parkinson, C.D., Upreti, B.N., 2005. Five generation of monazite in Langtang gneisses: implication for chronology of the Himalayan metamorphic core. Journal of Metamorphic Geology 23, 399-406.

Langone, A., Braga, R., Massonne, H.J., Tiepolo, M., 2011. Preservation of old (prograde metamorphic) U-Th-Pb ages in unshielded monazite from high-pressure paragneiss of the Variscan Ulten Zone. Lithos 127, 68-85.

Larson, K.P., Godin, L., Price, R.A., 2010. Relationships between displacement and distortion in orogens: linking the Himalayan foreland and hinterland in central Nepal. Geological Society of American Bulletin 122, 1116-1134.

Larson, K.P., Cottle, J.M., Godin, L., 2011. Petrochronologic record of metamorphism and melting in the upper Greater Himalayan sequences, Manaslu-Himal Chuli Himalaya, west-central Nepal. Lithosphere 3, 379-392.

Le Fort, P., 1975. Himalaya: the collided range. American Journal of Science 275, 1-44.

Le Fort, P., Rai, S.M., 1999. Pre-Tertiary felsic magmatism of the Nepal Himalaya: recycling of continental crust. Journal of Asian Earth Sciences 17, 607-628.

Leech, M.L., 2008. Does the Karakoram fault interrupt mid-crustal channel flow in the western Himalaya? Earth and Planetary Science Letters 276, 314-322.

Linthout, K., 2007. Tripartite division of the system $2 \mathrm{REEPO}_{4}-\mathrm{CaTh}\left(\mathrm{PO}_{4}\right)_{2}-2 \mathrm{ThSiO}_{4}$, discreditation of brabantite, and recognition of cheralite as the name for members dominated $\mathrm{CaTh}\left(\mathrm{PO}_{4}\right)_{2}$. The Canadian Mineralogist 45, 503-508.

Ludwig, K.R., 2000. ISOPLOT - A Geochronological Toolkit for Microsoft Excel. Special Publication No. 1a.Berkeley Geochronology Center, Berkeley, CA 1-53.

Macfarlane, A.M., 1993. Chronology of tectonic events in the crystallines core of the Himalaya, Langtang, National Park, central Nepal. Geological Society of America Bulletin 104, 1389-1402.

Martin, A.J., Ganguly, J., DeCelles, P.G., 2010. Metamorphism of Greater and Lesser Himalayan rocks exposed in the Modi Khola valley, central Nepal. Contributions to Mineralogy and Petrology 159, 203-223.

Martins, L., Vlach, S.R.F., Janasi, V.A., 2009. Reaction microtexture of monazite: correlation between chemical and age domains in the Nazaré Paulista migmatite, SE Brazil. Chemical Geology 261, 271-285.

Mukherjee, S., Koyi, H.A., Talbot, C., 2011. Implications of channel flow analogue models for extrusion of the Higher Himalayan Shear Zone with special reference to the out-of-sequence thrusting. International Journal of Earth Sciences (Geologische Rundschau). http://dx.doi.org/10.1007/s00531-011-0650-6.

Myrow, P.M., Hughes, N.C., Searle, M.P., Fanning, C.M., Peng, S.C., Parcha, S.K., 2009. Stratigraphic correlation of Cambrian-Ordovician deposits along the Himalaya: implications for the age and nature of rocks in the Mount Everest region. Geological Society of America Bulletin 121, 323-332.

Paquette, J.L., Tiepolo, M., 2007. High resolution ( $5 \mu \mathrm{m}) \mathrm{U}-\mathrm{Th}-\mathrm{Pb}$ isotope dating of monazite with excimer laser ablation (ELA)-ICPMS. Chemical Geology 240, 222-237

Parrish, R.R., 1990. U-Pb dating of monazite and its applications to geological problems. Canadian Journal of Earth Sciences 27, 1431-1450.

Passchier, C.W., Trouw, R.A.J., 2005. Microtectonics. In: Springer (Ed.), p. 366.

Patiño-Douce, A., Harris, N., 1998. Experimental constraints on Himalayan anatexis. Journal of Petrology 39, 689-710.

Platt, J.P., 1993. Exhumation of high-pressure rocks: a review of concept and processes. Terra Nova 5, 119-133.

Pyle, J.M., Spear, F.S., 1999. Yttrium zoning in garnet: coupling of major and accessory phase during metamorphic reactions. Geologica Material Research 1, 1-49.

Pyle, J.M., Spear, F.S., Wark, D.A., 2002. Electron microprobe analysis of REE in apatite, monazite and xenotime: protocols and pitfalls. Reviews in Mineralogy and Geochemistry 48, 337-362.

Reddy, S.P., Searle, M.P., Massey, J.A., 1993. Structural evolution of the High Himalayas gneiss sequences, Langatang Valley, Nepal. In: Treloar, P.J., Searle, M.P. (Eds.), Himalayan Tectonics, Special Publications, vol. 7. The Geological Society, London, pp. 375-389.

Rubatto, D., Williams, I.S., Buickm, I.S., 2001. Zircon and monazite response to prograde metamorphism in the Reynold Range, Central Australia. Contributions to Mineralogy and Petrology 140, 458-468.

Rubatto, D., Chakraborty, S., Dasgupta, S., 2012. Timescale of crustal melting in the Higher Himalayan Crystallines (Sikkim, Eastern Himalaya) inferred from trace element-constrained monazite and zircon chronology. Contributions to Mineralogy and Petrology. http://dx.doi.org/10.1007/s00410-012-0812-y. 
Searle, M.P., 1999. Extensional and compressional faults in the Everest-Lhotse Massif, Khumbu Himalaya, Nepal. Journal of the Geological Society of London 156, 227-240.

Searle, M.P., Godin, L., 2003. The South Tibetan Detachment System and the Manaslu Leucogranite: a structural reinterpretation and restoration of the AnnapurnaManaslu Himalaya, Nepal. Journal of Geology 111, 505-523.

Searle, M.P., Simpson, R.L., Law, R.D., Parrish, R.R., Waters, D.J., 2003. The structural geometry, metamorphic and magmatic evolution of the Everest massif, High Himalaya of Nepal-South Tibet. Journal of the Geological Society 160, 345-366.

Seydoux-Guillaume, A.M., Paquette, J.L., Wiedenbeck, M., Montel, J.M., Heinrich, W. 2002a. Experimental resetting of the U-Th-Pb systems in monazite. Chemical Geology 191, 165-181.

Seydoux-Guillaume, A.M., Wirth, R., Nasdala, L., Gottschalk, M., Montel, J.M., Heinrich, W., 2002b. An XRD, TEM and Raman study of experimentally annealed natural monazite. Physics and Chemistry of Minerals 29, 240-253.

Shelley, D., 1993. Igneous and Metamorphic Rocks Under the Microscope.Chapman and Hall, London.

Spear, F.S., 1993. Metamorphic phase equilibria and pressure-temperature-time paths. Mineralogical Society of America, Monograph Series, Washington, D.C.

Spear, F.S., 2010. Monazite-allanite phase relations in metapelites. Chemical Geology 279, 55-62.

Spear, F.S., Menard, T., 1989. Program GIBBS: a generalized Gibbs method algorithm. American Mineralogist 74, 942-943.

Spear, F.S., Pyle, J.M., 2002. Apatite, monazite, and xenotime in metamorphic rocks. Reviews in Mineralogy and Geochemistry 48, 293-335.

Spear, F.S., Pyle, J.M., 2010. Theoretical modeling of monazite growth in a low-Ca metapelite. Chemical Geology 273, 111-119.

Spear, F.S., Kohn, J.M., Florence, F.P., Menard, T., 1991. A model for garnet and plagioclase growth in pelitic schists: implications for thermobarometry and PT path determinations. Journal of Metamorphic Geology 8, 683-698.

Streule, M.J., Searle, M.P., Waters, M.P., Horstwood, M.S.A., 2010. Metamorphism, melting, and channel flow in Greater Himalayan Sequence and Makalu leucogranite: constraints from thermobarometry, metamorphic modeling, and U-Pb geochronology. Tectonics 29, TC5011. http://dx.doi.org/10.1029/2009TC002533.

Swapp, S.M., Hollister, S., 1991. Inverted metamorphism within the Tibetan slab of Bhutan: evidence for a tectonically transported heat sources. Canadian Mineralogist 29, 1019-1041.

Tera, F., Wasserburg, G.J., 1972. U-Th-Pb systematics in three Apollo 14 basalts and the problem of initial $\mathrm{Pb}$ in lunar rocks. Earth and Planetary Science Letters 14, 281-304.

Tiepolo, M., 2003. In situ Pb geochronology of zircon with laser ablation-inductively coupled plasma-sector field mass spectrometry. Chemical Geology 199, 159-177.
Todd, C.S., 1998. Limits on the precision of geobarometry at low grossular and anorthite content. American Mineralogist 83, 1161-1167.

Upreti, B.N., 1999. An overview of the stratigraphy and tectonics of the Nepal Himalaya. Journal of Asian Earth Sciences 17, 577-606.

van Achterbergh, E., Ryan, C.G., Jackson, S.E., Griffin, W., 2001. Data reduction software for LA-ICP-MS. In: Sylvester, P. (Ed.), Laser Ablation-ICPMS in the Earth Science: Mineralogical Association of Canada, 29, pp. 239-243.

Vannay, J.C., Grasemann, B., 2001. Himalayan inverted metamorphism and synconvergence extension as a consequence of a general shear extrusion. Geological Magazine 138 253-276.

Vannay, J.C., Hodges, K.V., 1996. Tectonometamorphic evolution of the Himalayan metamorphic core between the Annapurna and Dhaulaghiri, Central Nepal. Journal of Metamorphic Geology 14, 635-656.

Visonà, D., Lombardo, B., 2002. Two-mica and tourmaline leucogranites from EverestMakalu region (Nepal-Tibet). Himalayan leucogranites genesis by isobathic heating? Lithos 62, 125-150.

Visonà, D., Carosi, R., Montomoli, C., Peruzzo, L., Tiepolo, M., 2012. Miocene andalusite leucogranite in central-east Himalaya (Everest-Masang Kang area): low-pressure melting during heating. Lithos 144, 194-208.

Webb, A.A.G., Yin, A., Harrison, T.M., Célérier, J., Burgess, P.W., 2007. The leading edge of the Greater Himalayan Crystalline complex revealed in the NW Indian Himalaya implications for the evolution of the Himalayan orogen. Geology 35, 955-958.

Whitney, D.L., Evans, B.W., 2010. Abbreviation for names of rock-forming minerals. American Mineralogist 95, 185-187.

Williams, M.L., Jercinovic, M.J., 2002. Microprobe monazite geochronology: putting absolute time into microstructural analysis. Journal of Structural Geology 24, 1013-1028.

Wu, C.M., Cheng, B.H., 2006. Valid garnet-biotite (GB) geothermometry and garnetaluminum silicate-plagioclase-quartz (GASP) geobarometry in metapelitic rocks. Lithos 89, 1-23.

Wu, C.M., Zhao, G.C., 2006. Recalibration of the garnet-muscovite (GM) geothermometer and the garnet-muscovite-plagioclase-quartz (GMPQ) geobarometer for metapelitic assemblages. Journal of Petrology 47, 2357-2368.

Wu, C.M., Zhang, J., Ren, L.D., 2004. Empirical garnet-biotite-plagioclase-quartz (GBPQ) geobarometry in medium- to high grade metapelites. Journal of Petrology 45, 1907-1921.

Yakymchuck, C.J.A., Godin, L., 2012. Coupled role of deformation and metamorphism in the construction of inverted metamorphic sequences: an example from farnorthwest Nepal. Journal of Metamorphic Geology 30, 513-535. 